\title{
Topical Application of Double-Stranded RNA Targeting $2 b$ and CP Genes of Cucumber mosaic virus Protects Plants against Local and Systemic Viral Infection
}

\author{
Maria C. Holeva ${ }^{1}$, Athanasios Sklavounos ${ }^{2,3}$, Rajendran Rajeswaran ${ }^{4}$, Mikhail M. Pooggin ${ }^{5}$ \\ and Andreas E. Voloudakis 2,*(D) \\ 1 Laboratory of Bacteriology, Scientific Directorate of Phytopathology, Benaki Phytopathological Institute, \\ 14561 Kifissia, Greece; m.holeva@bpi.gr \\ 2 Laboratory of Plant Breeding and Biometry, Department of Crop Science, Agricultural University of Athens, \\ 11855 Athens, Greece; thansclav@yahoo.gr \\ 3 Office of Rural Development and Inspections of Kephalonia, Ministry of Rural Development and Food, \\ 28100 Argostoli, Greece \\ 4 Department of Biology, Swiss Federal Institute of Technology (ETH), Universitätsstrasse 2, \\ 8092 Zürich, Switzerland; r.rajeswar@gmail.com \\ 5 PHIM Plant Health Institute, University of Montpellier, 34980 Montpellier, France; mikhail.pooggin@inrae.fr \\ * Correspondence: avoloud@aua.gr; Tel.: +30-2105294213
}

\section{check for} updates

Citation: Holeva, M.C.; Sklavounos, A.; Rajeswaran, R.; Pooggin, M.M.; Voloudakis, A.E. Topical Application of Double-Stranded RNA Targeting $2 \mathrm{~b}$ and $\mathrm{CP}$ Genes of Cucumber mosaic virus Protects Plants against Local and Systemic Viral Infection. Plants 2021, 10, 963. https://doi.org/ $10.3390 /$ plants10050963

Academic Editor: Alexandra S. Dubrovina

Received: 7 February 2021

Accepted: 8 April 2021

Published: 12 May 2021

Publisher's Note: MDPI stays neutral with regard to jurisdictional claims in published maps and institutional affiliations.

Copyright: (c) 2021 by the authors. Licensee MDPI, Basel, Switzerland. This article is an open access article distributed under the terms and conditions of the Creative Commons Attribution (CC BY) license (https:// creativecommons.org/licenses/by/ $4.0 /)$.

\begin{abstract}
Cucumber mosaic virus (CMV) is a destructive plant virus with worldwide distribution and the broadest host range of any known plant virus, as well as a model plant virus for understanding plant-virus interactions. Since the discovery of RNA interference (RNAi) as a major antiviral defense, RNAi-based technologies have been developed for plant protection against viral diseases. In plants and animals, a key trigger of RNAi is double-stranded RNA (dsRNA) processed by Dicer and Dicerlike (DCL) family proteins in small interfering RNAs (siRNAs). In the present study, dsRNAs for coat protein $(\mathrm{CP})$ and $2 \mathrm{~b}$ genes of $\mathrm{CMV}$ were produced in vitro and in vivo and applied onto tobacco plants representing a systemic solanaceous host as well as on a local host plant Chenopodium quinoa. Both dsRNA treatments protected plants from local and systemic infection with CMV, but not against infection with unrelated viruses, confirming sequence specificity of antiviral RNAi. Antiviral RNAi was effective when dsRNAs were applied simultaneously with or four days prior to CMV inoculation, but not four days post inoculation. In vivo-produced dsRNAs were more effective than the in vitroproduced; in treatments with in vivo dsRNAs, dsRNA-CP was more effective than dsRNA-2b, while the effects were opposite with in vitro dsRNAs. Illumina sequencing of small RNAs from in vivo dsRNA-CP treated and non-treated tobacco plants revealed that interference with CMV infection in systemic leaves coincides with strongly reduced accumulation of virus-derived 21- and 22-nucleotide (nt) siRNAs, likely generated by tobacco DCL4 and DCL2, respectively. While the 21-nt class of viral siRNAs was predominant in non-treated plants, 21-nt and 22-nt classes accumulated at almost equal (but low) levels in dsRNA treated plants, suggesting that dsRNA treatment may boost DCL2 activity. Taken together, our findings confirm the efficacy of topical application of dsRNA for plant protection against viruses and shed more light on the mechanism of antiviral RNAi.
\end{abstract}

Keywords: Cucumber mosaic virus; RNAi; double-stranded RNA; dsRNA vaccination; small interfering RNAs

\section{Introduction}

RNA interference (RNAi) is an evolutionarily conserved mechanism, present in eukaryotic organisms, that regulates gene expression via mRNA degradation, repression of translation, and chromatin remodeling [1]. It is involved in developmental regulation, stress response, or defense against invading nucleic acids like transposons or viruses [2]. Its role as a natural antiviral defense system in plants, invertebrates, and mammals has 
been well documented [3-7] and is considered together with the RNA decay and RNA quality-control pathways as ancestral forms of an antiviral immunity which may operate cooperatively for their antiviral function [8].

As our understanding of the RNAi mechanism deepens, the potential to exploit this mechanism in plant pest control has long attracted research interest, especially against viruses since preventive or control plant protection measures against viral diseases are very limited and the public pressure for adoption of environmentally-friendly crop protection strategies is constantly increasing. The main research focus in this direction has been the development of transgenic plants aiming at induction of RNAi that led to attenuation or elimination of viral disease symptoms. To this respect, diverse plant-virus pathosystems have been studied and crops engineered for virus resistance have been developed, using among others so-called RNAi transgenes designed to express dsRNA as a key trigger of RNAi $[9,10]$. Furthermore, certain engineered crops such as squash resistant to Watermelon mosaic virus 2, Zucchini yellow mosaic virus (ZYMV) and Cucumber mosaic virus (CMV), papaya resistant to Papaya ringspot virus, potato resistant to Potato virus $Y$, bean resistant to Bean golden mosaic virus, tomato, and sweet pepper resistant to CMV have been approved for commercial production [11].

However, as public opinion for transgenic plants in several parts of the world is not favorable and often even opposing, RNAi-induced resistance via alternative non-transgenic approaches is gaining ground. The topical application of RNA molecules on plants, also designated as plant 'RNA vaccination', is one of these approaches for induction of the RNAi mechanism in plants against viruses. Tenllado and Díaz-Ruíz [12] applied successfully by mechanical inoculation in vitro produced dsRNA molecules derived from viral sequences to 'vaccinate' Nicotiana benthamiana plants against Pepper mild mottle virus (PM$\mathrm{MoV})$, Tobacco etch virus and Alfalfa mosaic virus, showing that these molecules can interfere with virus infection in a sequence-specific manner. Similarly, in vivo produced dsRNA molecules in bacterial cells promoted specific interference with the infection in N. benthamiana plants by PMMoV and Plum pox virus [13]. Many more plant-virus combinations have since been investigated regarding the effectiveness of topical application of dsRNA molecules against the cognate virus pathogen, as reviewed recently by Mitter et al. [14], Voloudakis et al. [15] and Dalakouras et al. [16].

In plant RNAi defense against RNA viruses, dsRNA intermediates of viral replication are processed by Dicer-like (DCL) family proteins DCL4 and DCL2 into 21- and 22nucleotide (nt) small interfering RNAs (siRNAs), respectively. These siRNAs bind to Argonaute (AGO) family proteins and guide the resulting RNA-induced silencing complexes (RISCs) to target viral RNAs for cleavage and degradation or translational repression. DNA viruses are additionally targeted by nuclear DCL3 processing viral dsRNA generated by sense and antisense transcription into 24-nt siRNAs (reviewed in [17]). Transgenic expression of dsRNA cognate to both RNA and DNA viruses can confer virus resistance, likely by pre-inducing and/or boosting the antiviral RNAi responses (reviewed in [10]).

To counteract the plant antiviral RNAi-based mechanism and successfully induce disease, the plant viruses have evolved to encode proteins that act as suppressors of RNAi (viral suppressors of RNA silencing, VSRs). It has been shown that VSRs can interfere and block almost any stage of RNAi pathway [2]. Thus, a key issue determining the outcome of the race between a pathogenic virus and its host plant is when the RNAi is triggered by dsRNA.

In the present study, the dsRNA vaccination approach was applied against CMV, the type species of the genus Cucumovirus in the family Bromoviridae. CMV has a worldwide distribution and above all the broadest host range of any known plant virus, infecting more than 1000 species of plants, including monocots and dicots, herbaceous plants, shrubs, trees, agricultural crops, ornamentals and wild species [18]. CMV can be transmitted by at least 86 aphid species in a non-persistent manner, corresponding to the noncirculative mode $[19,20]$. Most of the infected hosts develop systemic mosaic symptoms, more or less severe depending on the host genotype and the strain, as well as mosaics of light 
and dark green areas on the infected leaves [21,22]. CMV disease outbreaks in tomato, pepper, or cucurbits, crops with high commercial interest, usually result in great economic losses [23-26]. The disease symptoms in tomato include leaf and plant shrinkage, upward leaf curling, vein purpling, chlorosis, pericarp hardening and discoloration, plant and fruit necrosis, and even plant death $[20,23-25,27]$. The common symptoms of CMV on tobacco plants (Nicotiana tabacum cv. 'Xanthi') are stunting, deformations, and mild mosaic on leaves, while a few CMV strains induce yellow mosaic on tobacco leaves [28,29]. So far, control of CMV depends mainly on the use of pesticides against insect vectors, resistant or tolerant varieties and cross-protection [23]. In addition, pathogen-derived resistance (PDR) has been demonstrated against CMV using various segments of the CMV genome [30].

The genome of CMV consists of three single-stranded positive-sense RNA species (RNA 1, RNA 2, RNA 3) and a subgenomic RNA (RNA 4) which is transcribed from RNA3 to serve as mRNA for the viral coat protein (CP). Viral CP encoding genes are the most frequently used genes in plant transformation for PDR and proved to be efficient in many cases $[19,31,32]$. CP-mediated resistance is achieved through post-transcriptional gene silencing (PTGS) and has been used to create CMV resistant plant species including tobacco, cucumber, tomato, melon, squash and pepper [31,33-36]. In one study, tobacco was transformed with an RNAi construct containing an inverted-repeat of a 747-bp fragment of the CMV CP separated by a spacer, and the obtained plant lines with two or more copies of the transgenes were resistant to $\mathrm{CMV}$ infection [37]. Likewise, $N$. benthamiana transgenic plants were produced with $100 \%$ resistance to CMV, using an RNAi transgene with CMV $\mathrm{CP}$ inverted-repeat sequences separated by an intron [38].

Apart from the viral CP genes, other gene targets used to engineer plant resistance include VSRs, such as the CMV $2 \mathrm{~b}$ protein [39]. The CMV 2b protein is a multifunctional protein involved in host-specific, long-distance movement, symptom induction, and acts as a virulence determinant by suppressing plant RNAi and gene silencing pathways. CMV $2 \mathrm{~b}$ inhibits siRNA-directed local and systemic silencing by sequestering siRNA duplexes and / or blocking antiviral activity of AGO1 (reviewed in [2]). Qu et al. [40] demonstrated that transgenic expression in tobacco of the $2 b$-specific artificial miRNA is an effective method to protect hosts from infection by CMV. Additionally, there have been reports of tobacco and tomato plants transgenic for $\mathrm{CMV}$ replicase showing a variable degree (0 to $100 \%$ ) of resistance depending on the challenging CMV strain (subgroup) [31].

In the present study, we show that topical application of dsRNA derived from $\mathrm{CP}$ and $2 \mathrm{~b}$ gene sequences of CMV can protect tobacco plants from systemic infection of CMV as well as reduce local lesions on leaves of the local host Chenopodium quinoa. Using deep small RNA sequencing and bioinformatics, we demonstrate that dsRNA-mediated interference with systemic CMV infection coincides with strongly reduced accumulation of 21- and 22-nt viral siRNAs and alteration in their ratio, indicative of changes in relative activities of DCL4 vs. DCL2.

\section{Results}

DsRNA molecules were produced using the in vitro and in vivo methods, previously described by Voloudakis et al. [41] and schematically depicted in Supplementary Figure S1. Both in vitro and in vivo dsRNAs for CMV CP (657 bps) and $2 \mathrm{~b}$ (336 bps), resistant to DNase and RNase A treatments, were produced in sufficient quantities [ $3-4 \mu \mathrm{g} / \mu \mathrm{L}$ in vitro dsRNA-CP (dsCP) or in vitro dsRNA-2b (ds2b) or in vivo ds $2 b ; 0.1-0.3 \mu \mathrm{g} / \mu \mathrm{L}$ in vivo $\mathrm{dsCP}$; as estimated on agarose gel after RNase A/DNase I treatment, Supplementary Figure S2], and then tested for their protective effects against CMV infection in Nicotiana tabacum and C. quinoa plants.

2.1. dsRNA Treatments of Tobacco Plants Resulted in Variable Levels of Protection against CMV Infection, Which Depended on the dsRNA Construct Used and the Timing of Virus Inoculation

All N. tabacum plants treated with CMV inoculum alone $(n=157)$ or CMV inoculum in mixture with in vivo produced dsRNA-MalE (dsMalE) $(n=19)$, used as a control for sequence specificity of dsRNA, became infected after 14 days post inoculation (dpi), show- 
ing typical CMV symptoms including leaf curl/bump-like symptoms, mosaic symptoms, dwarfing of plants and necrosis of leaves. These results confirmed that the CMV inoculum used was infectious and the environmental conditions applied were appropriate for symptom development on tobacco plants. The dsMalE, that does not share sequence homology with CMV, did not prevent CMV infection, thus confirming the sequence specific nature of the antiviral RNAi. All 38 tobacco plants, mock-inoculated with sterile distilled water instead of CMV, remained healthy.

When the dsRNA molecules had sequence homology with CMV, variable levels of protection against CMV infection were observed at $14 \mathrm{dpi}$ in three repeated experiments. The co-application of in vitro produced dsCP together with CMV on a total of 60 plants provided $10 \%$ protection, while in vitro produced ds $2 \mathrm{~b}$ protected from CMV infection 35 to $65 \%$ of the co-inoculated plants $(n=60)$. When the in vitro produced dsCP and $\mathrm{ds} 2 \mathrm{~b}$ molecules were applied jointly, the protection level ranged from 45 to $55 \%$ of the co-inoculated plants $(n=40)$. For this treatment, the number of plants taken into account was 40 instead of 60 because in one replicate the infectivity of CMV in control plants was $75 \%$ rather than $100 \%$, and thus this replicate was not further considered. In the case of in vivo produced dsRNA molecules, the application of dsCP protected from CMV infection $85 \%$ of co-inoculated plants $(n=60)$, while ds $2 \mathrm{~b}$ protected 40 to $75 \%$ of co-inoculated plants $(n=60)$. When both in vivo dsRNA molecules were applied simultaneously, the protection ranged between 80 to $100 \%$ of the co-inoculated plants $(n=60)$. (Figures $1-3)$. Tukey HSD test showed that the protective effect of the in vitro $d s 2 b$ was not significantly different to that of the in vivo ds $2 b$ or the joint application of in vitro ds $2 b$ and in vitro dsCP. Similarly, the in vivo ds2b was not significantly different to in vivo dsCP or to their joint application. On the contrary, in vitro dsCP was significantly less effective $(p<0.05)$ than any other treatment, and especially in comparison with the in vivo dsCP.

100

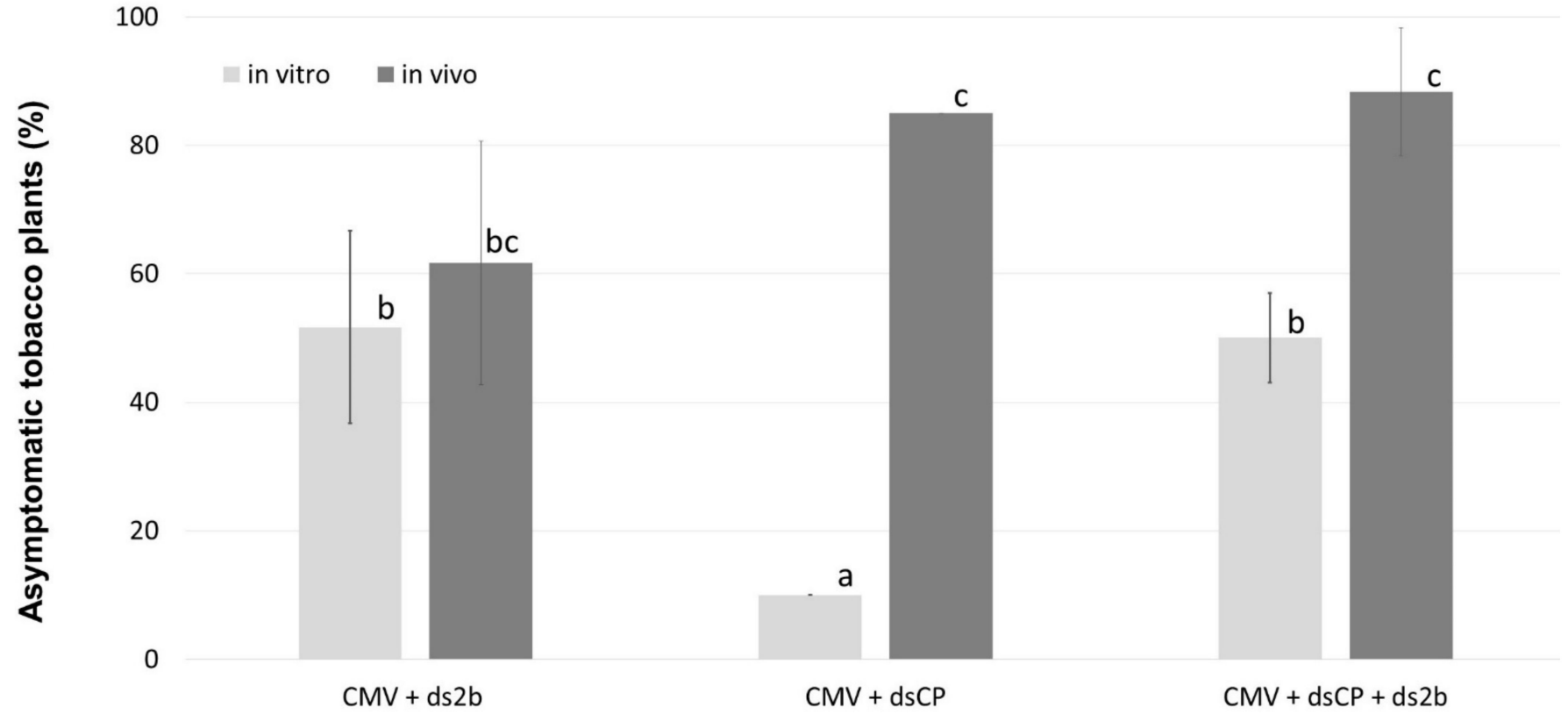

Treatment

Figure 1. dsRNAs derived from CMV sequences confer a varied level of resistance to tobacco plants against the cognate virus. The histogram shows the percentage of asymptomatic plants determined for each treatment of tobacco plants with in vitro or in vivo produced dsRNA molecules. Data represent mean of the replicates \pm standard deviation. Letters indicate the significant differences $(p<0.05)$ between the bars (Tuckey HSD test). 


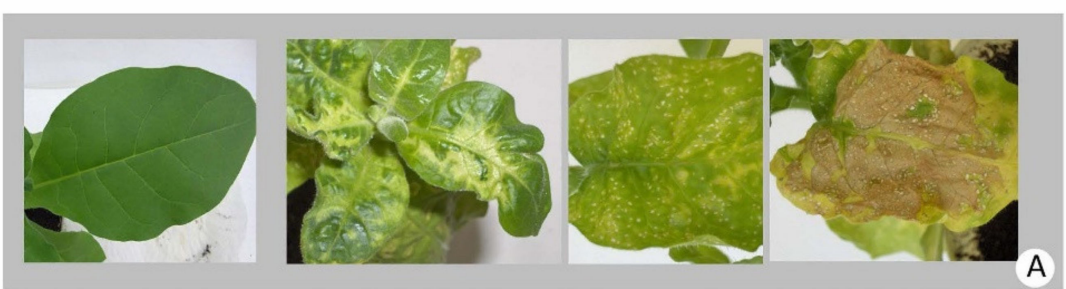

\section{CMV}

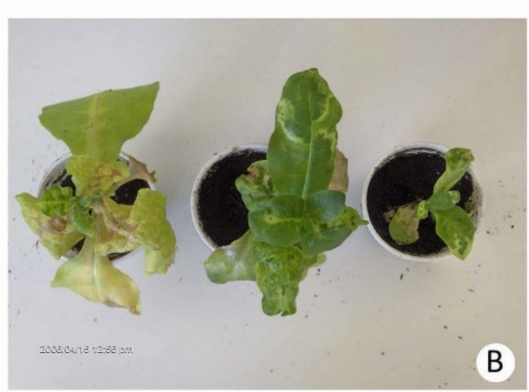

$\mathrm{CMV}+$ in vitro dsCP

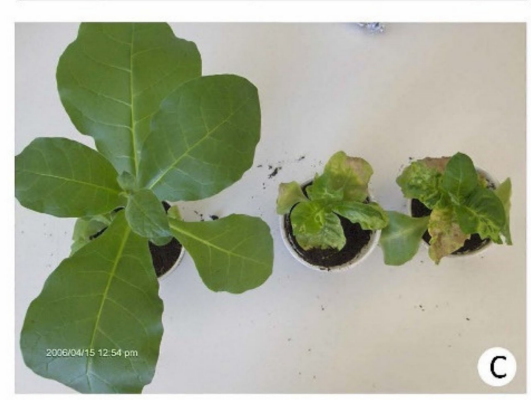

$\mathrm{CMV}+$ in vitro ds2b

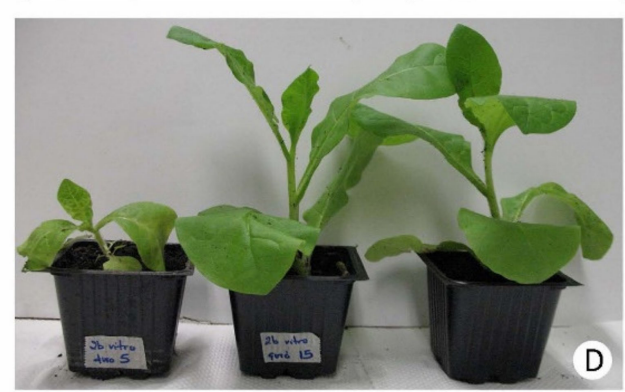

Figure 2. In vitro produced dsRNA molecules confer resistance to tobacco against CMV. (A) Range of symptoms of CMVinfected plants in comparison with the mock (water) inoculated plants. (B-D) Response of tobacco plants to the application of CMV jointly with in vitro produced dsRNA derived from the cognate virus. The tobacco plants were inoculated with: CMV (B), CMV jointly with in vitro dsCP (C) or CMV jointly with in vitro ds2b (D). Plants were photographed at $14 \mathrm{dpi}$.

CMV

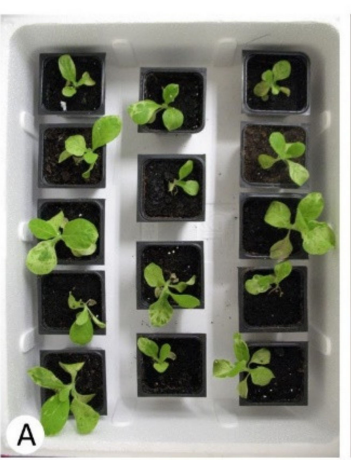

$\mathrm{CMV+}$

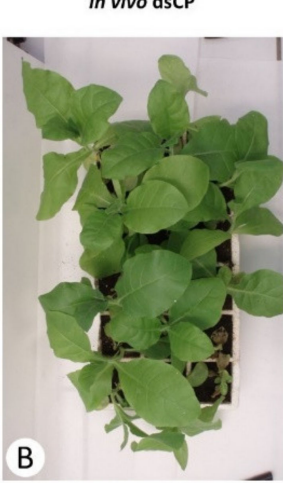

$\mathrm{CMV}+$

in vivo ds $2 \mathrm{~b}$

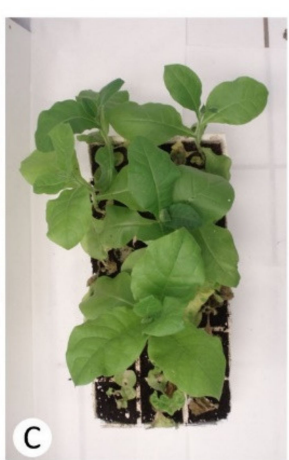

$\mathrm{CMV}+$

in vivo ds $\mathrm{CP}+$ in vivo ds $2 \mathrm{~b}$

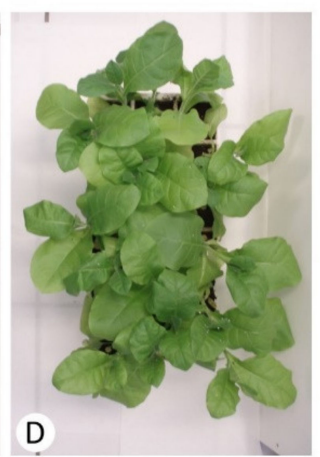

Mock inoculated plant
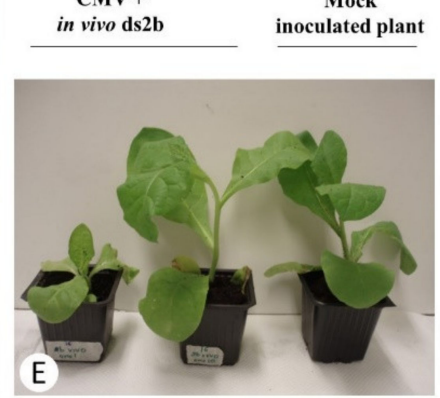

Figure 3. In vivo produced dsRNA molecules confer resistance to tobacco against CMV. Response of tobacco plants to the application of CMV jointly with in vivo produced dsRNA derived from the cognate virus. The tobacco plants were inoculated with: (A) CMV, (B) CMV jointly with in vivo dsCP, (C) CMV jointly with in vivo ds2b, (D) CMV jointly with in vivo dsCP and in vivo ds2b, (E) CMV jointly with in vivo ds2b in comparison with a mock (water) inoculated plant. Plants were photographed at $21 \mathrm{dpi}$.

Regarding the time-course of symptom development recorded in one of the three repeated experiments, we observed that when the $N$. tabacum plants were inoculated only with $\mathrm{CMV}, 18 \%$ of the plants $(n=11)$ remained asymptomatic at $7 \mathrm{dpi}$ and $0 \%$ of the plants were asymptomatic at $14 \mathrm{dpi}$. In contrast, for plants $(n=13)$ co-inoculated with CMV and in vitro ds $2 \mathrm{~b}$, the asymptomatic plants were $77 \%$ at $7 \mathrm{dpi}, 62 \%$ at $14 \mathrm{dpi}$, and $38 \%$ at $19 \mathrm{dpi}$. Thus, the application of in vitro ds $2 b$ delayed symptom development.

To test the protective action of the dsRNA molecules when applied on N. tabacum plants prior or after to CMV inoculation, the in vivo produced dsCP was selected, because it was the most protective in the co-inoculation experiments and applied either four days 
before or four days after CMV inoculation, or simultaneously with CMV. At $15 \mathrm{dpi}$, protection was observed only when the dsRNA molecules were applied simultaneously $(n=20)$ or 4 days before CMV inoculation $(n=20)$, with a percentage of asymptomatic plants being $65 \%$ and $35 \%$, respectively. On the contrary, all plants $(n=20)$ were symptomatic when the application of dsCP was delayed for 4 days after CMV inoculation.

To test sequence specificity of the dsRNA protective effects, the in vivo produced $\mathrm{ds} 2 \mathrm{~b}$ was applied in mixtures with inoculum of unrelated viruses including Tobacco mosaic virus (TMV) $(n=20)$, Potato virus Y (PVY) $(n=20)$, or Tobacco rattle virus (TRV) $(n=20)$. All the treated plants became infected with the corresponding viruses after 21 days, displaying the characteristic disease symptoms for TMV, PVY, or TRV. In contrast, co-application of the in vivo ds $2 b$ in mixture with CMV, $55 \%$ of the co-inoculated tobacco plants $(n=20)$ remained asymptomatic after 21 days. This confirms the sequence specificity of ds $2 b$ protective effect against $\mathrm{CMV}$, i.e., the virus from which the dsRNA sequence derived, but not against the unrelated viruses lacking any $2 \mathrm{~b}$ gene homology.

\section{2. dsRNA Treatment Protects from Local Infection in Chenopodium Quinoa Plants}

We then tested dsRNA effects on local lesions of CMV infection on C. quinoa, a local lesion host plant of CMV. When leaves of $C$. quinoa were treated with CMV alone or CMV in mixture with in vitro dsRNA molecules, the average number of local necrotic lesions per leaf formed at 6 dpi was: 45 for CMV-treated leaves $(n=10), 14.5$ for leaves treated with CMV and dsCP $(n=10), 2.6$ for leaves treated with CMV and ds2b $(n=10)$, and 16.3 for leaves treated with CMV, dsCP and ds2b $(n=10)$ (Figure S3). Tukey HSD test analysis showed that the leaves treated with the dsRNA molecules exhibited a significantly $(p<0.01)$ lower number of lesions in comparison with the leaves treated only with CMV. Based on the same test, there was no significant difference $(p<0.05)$ between the protective effect of $\mathrm{ds} 2 \mathrm{~b}, \mathrm{dsCP}$, or their joint application. However, it is worth noting that the application of $\mathrm{ds} 2 \mathrm{~b}$ resulted in the lowest number of lesions per leaf, but this protective effect seems to be lost when it is jointly applied with dsCP, possibly due to dilution effect on this local host (Figure 1).

\section{3. dsRNA Treatment Leads to Reduced Accumulation of Viral siRNAs and Alteration in Their} Size Profile in Systemic Leaves

Systemic leaves from symptomatic (CMV-infected), asymptomatic (treated with in vivo dsCP or ds2b) and control (non-inoculated/non-treated) tobacco plants at $21 \mathrm{dpi}$ were used for total RNA extraction, followed by analysis of viral siRNA accumulation, genome distribution and size-class profiles using small RNA blot hybridization and Illumina sequencing.

Blot hybridization analysis using viral strand-specific oligonucleotide probes revealed accumulation of abundant, virus-derived 21-22 nt siRNAs of both polarities in all leaf samples from CMV-infected N. tabacum plants (Figure 4, lanes 2, 6, 10). In contrast, viral siRNAs were below detection level in systemic leaves of all the dsRNA-treated plants (Figure 4, lanes 3, 4, 7, 8, 11, 12) or the negative control plant (Figure 4, lane 1, 5, 9).

Illumina small RNA sequencing analysis of selected samples of the CMV-infected, $\mathrm{dsCP}$ - treated and control plants revealed that viral siRNAs do accumulate in systemic leaves of the plant co-inoculated with $\mathrm{CMV}$ and dsCP, albeit at much lower levels $(0.08 \%$ of total plant + virus reads) than in systemic leaves of the plant inoculated with CMV alone (17.90\% of total reads) (Figure 5a). Only negligible number of viral reads were detected in the control plant ( 475 reads, or $0.002 \%$ of total reads which can be considered as the crosscontamination level between these three libraries sequenced in one lane of Illumina Genome Analyzer). Despite the drastic difference in accumulation levels, in both CMV-infected and dsRNA-treated plants viral siRNAs were derived from all three CMV genomic RNAs, with RNA3 being the biggest siRNA producer, followed by RNA2 and RNA1 (Figure 5b) and represented both sense and antisense strands with similar hotspot profiles between the plants (Figure 6a vs. Figure 6b). Notably, the size-class profile of viral siRNAs differed between the CMV-infected plant accumulating predominantly 21-nt size-class, followed by 
3-times less abundant 22-nt class, and the dsRNA-treated plant accumulating 21-nt and 22-nt classes at almost equal levels (Figure 5c). Other size classes were underrepresented in both cases, consistent with the major role of DCL4 and DCL2 in RNAi-based defense against cytoplasmic RNA viruses such as CMV and previous studies on the biogenesis of CMV-derived siRNAs in Arabidopsis [42,43]. Despite the substantial alteration in the ratio of the two major size classes of CMV siRNAs (Figure 5c), the hot spot distribution along sense and antisense strands of the virus genome were similar for each size class between the plants (Figure 6a vs. Figure 6b), suggesting that dsRNA treatment may have altered relative activities of DCL4 and DCL2 rather than relative accumulation of viral siRNA precursors from the three genomic RNAs.

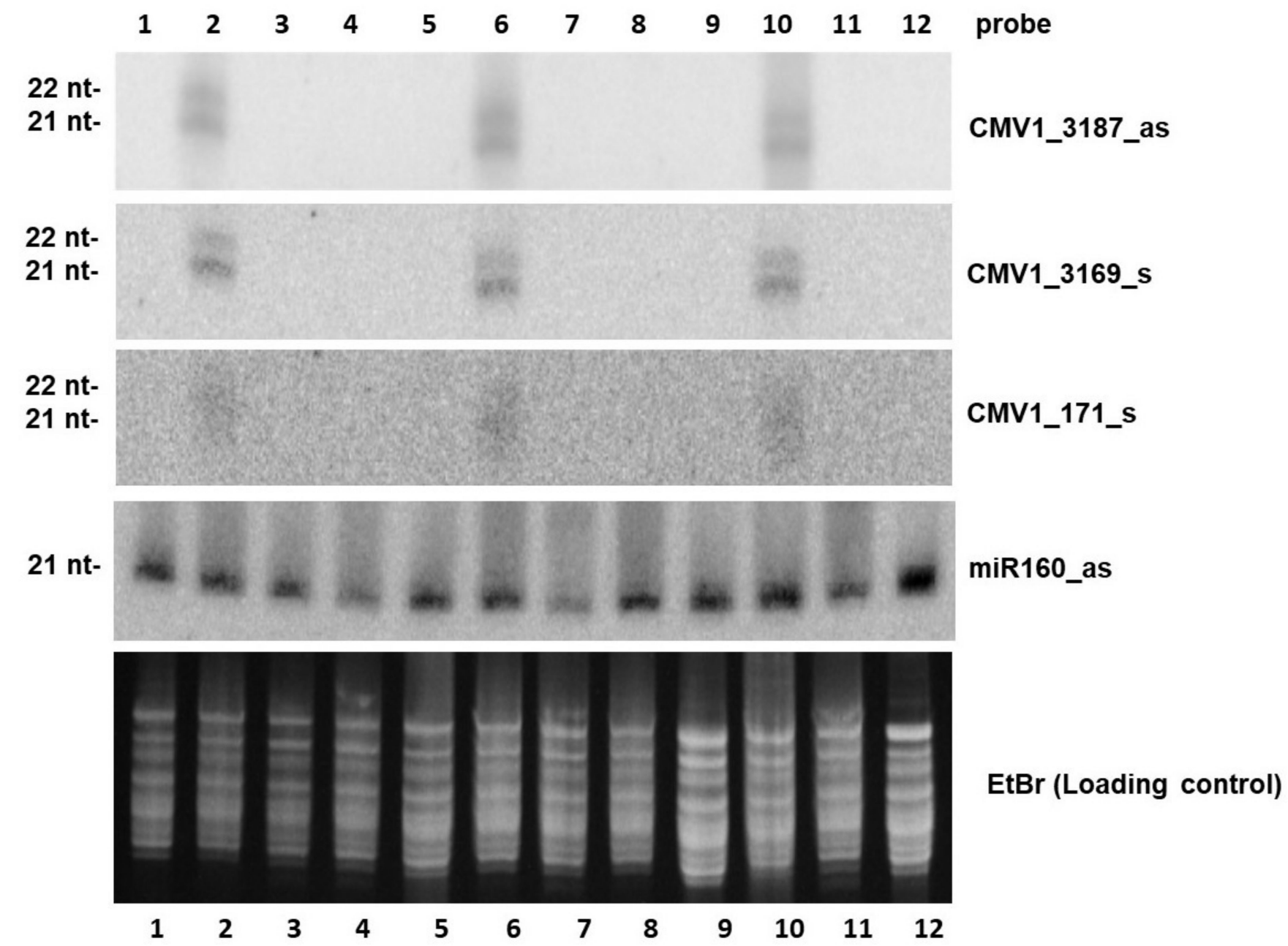

Figure 4. Small RNA blot hybridization analysis of CMV-infected, dsRNA treated and negative control tobacco plants. Total RNA samples resolved by electrophoresis on a $15 \%$ polyacrylamide gel stained with ethidium bromide (EtBr) and then transferred to a nylon membrane. The membrane was successively hybridized with $\mathrm{p}^{32}$-labeled DNA oligonucleotide probes specific to CMV RNA1-derived antisense (CMV1_3169_s and CMV1_171_s) and sense (CMV1_3187_as) siRNAs and plant miRNA160 (miR160_as). After each hybridization, the membrane was exposed to a phosphor screen for 20 hrs to 6 days and then scanned using a Phosphor Imager. The RNA samples are derived from: the 3rd leaf of mock inoculated plants (Lanes 1, 5, 9); a pool of leaves from plants inoculated with CMV showing symptoms (Lanes 2, 6, 10); the 3rd leaf (Lanes $3,4,7$ ) or the 2nd leaf (Lane 11) or the 4th leaf (Lane 12) of a plant inoculated with CMV and treated with in vivo $\mathrm{dsCP}$, not showing symptoms; the 3rd leaf of a plant inoculated with CMV and treated with in vivo ds2b, not showing symptoms (Lane 8). 

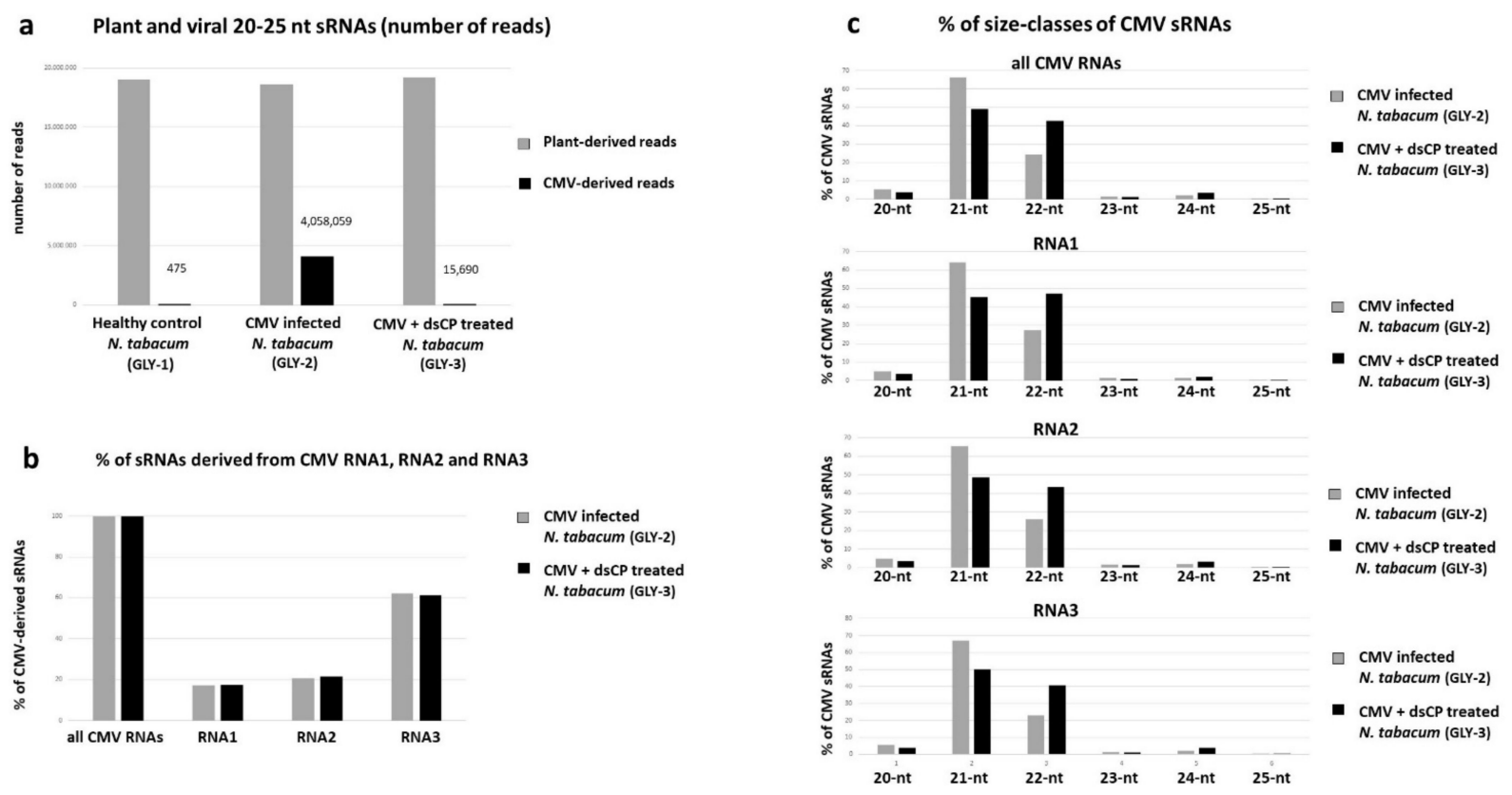

Figure 5. Illumina sequencing counts of endogenous and viral small RNAs (sRNAs) in healthy control (GLY-1), CMVinfected (GLY-2) and in vivo dsCP treated (GLY-3) tobacco plants. The 20- to 25-nt sRNA reads from GLY-1, GLY-2, and GLY-3 plants were mapped to the complete virus genome (CMV) or each of the individual CMV genomic RNA (RNA1, RNA2, RNA3) reference sequences with up to 2 mismatches and were counted. (a) The counts of CMV genome-derived 20-25 nt sRNA reads and total non-CMV reads in each library. (b) Percentage of each of the individual viral RNA-derived 20-25 nt sRNAs (RNA1, RNA2, RNA3) in the pool of the complete CMV genome-derived 20- to 25-nt sRNAs (CMV all). (c) Percentage of each size class in the 20- to 25-nt pools of the complete virus genome (CMV all)- and each genomic RNA (RNA1, RNA2, RNA3)-derived sRNA reads.
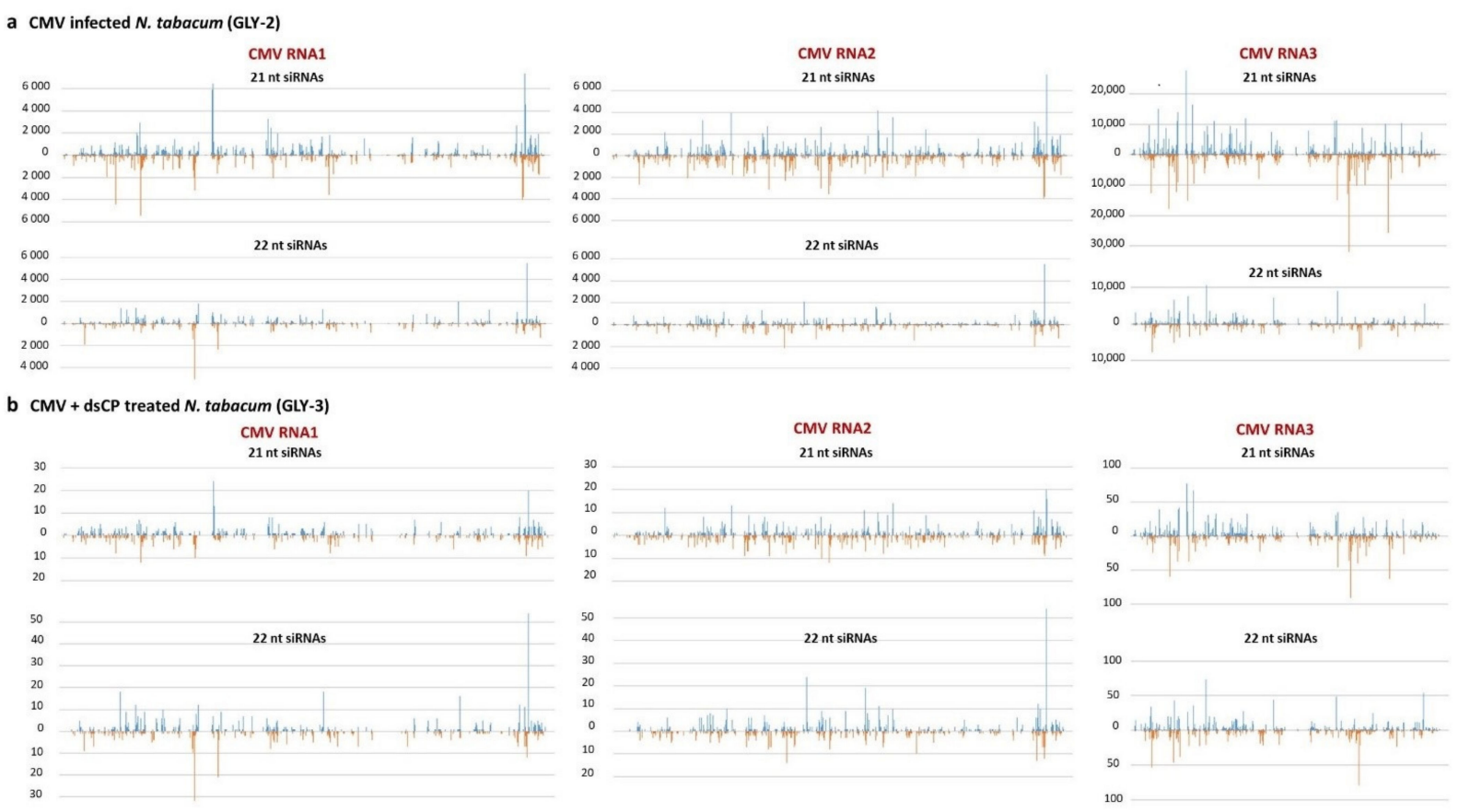

Figure 6. Single-nucleotide resolution maps of virus-derived small interfering RNAs (siRNAs) from: (a) CMV-infected (GLY-2) and (b) in vivo dsCP treated (GLY-3) tobacco plants. For each plant sample, the histograms plot the numbers of 21 and $22 \mathrm{nt}$ viral siRNA reads at each nucleotide position of the CMV genomic RNAs RNA1 (3361 nt), RNA2 (3060 nt), and RNA3 (2216 nt) (mapped with up to 2 mismatches). The bars above the axis represent sense (forward) reads starting at each position and those below represent antisense (reverse) reads ending at the respective position. 


\section{Discussion}

From the first report by Tenllado and Diaz-Ruiz [12] until today, the topical application of RNA molecules has been tested against a series of plant viruses and viroids including Alfalfa mosaic virus, Cymbidium mosaic virus, Pepper mild mottle virus, Plum pox virus, Papayaringspot virus, Pea seed borne mosaic virus, Potato virus $Y$, Sugarcane mosaic virus, Tobacco etch virus, Tobacco mosaic virus, Chryanthemum chlorotic mottle viroid, Citrus exocortis viroid, Potato spindle tuber viroid (reviewed in [14,15]), Zucchini yellow mosaic virus [44], Tomato leaf curl virus [45] and more recently Tomato spotted wilt virus [46], and Tomato yellow leaf curl virus [47].

Regarding CMV, initial data on tobacco RNA vaccination employing in vitro and in vivo dsRNA were initially reported by Holeva et al. [48,49] and on pepper RNA vaccination employing in vivo ds2b by Borah et al. [50]. Likewise, Mitter et al. [51] reported that spray application of in vitro ds $2 b$ on leaves of cowpea plants conferred plant resistance to CMV, but only if the leaves were virally challenged within 5 days post-dsRNA application. However, when the ds $2 \mathrm{~b}$ was loaded on layered double hydroxide nanosheets as carriers, the sprayed tobacco plants remained protected for at least 20 days after CMV inoculation. Such a non-toxic, biodegradable and biocompatible clay-based matrix as carrier of dsRNA was used to enhance the stability of the dsRNA molecules on the leaf surface of the field crop, as well as to achieve gradual release of these molecules, thus managing longer protection of the treated plants against CMV infection. Although transgenic tobacco plants expressing the CMV CP were found to exhibit CMV resistance [37], there is no experimental evidence on a similar plant response in case of topical application of dsRNA homologous to CMV CP.

In this study, we investigated the efficiency of long dsRNA molecules since it has been suggested that short dsRNA molecules (e.g., having a length of $300 \mathrm{bp}$ or less) exhibit reduced RNAi efficiency against plant viruses [12]. DsRNAs homologous to CMV CP (encoded by RNA 3) were compared to dsRNAs for CMV $2 b$ (encoded by RNA 2 ) in their ability to protect tobacco plants against CMV. Both dsRNA molecules were produced by in vitro and in vivo methods, as previously described [41]. In the bioassays performed, it was observed that dsRNA targeted to $\mathrm{CP}$ and $2 \mathrm{~b}$ of $\mathrm{CMV}$ conferred varied levels of protection against CMV, depending on the host plant and the dsRNA production method used (in vitro or in vivo). The protective impact of applying a combination of these two dsRNA molecules was also evaluated.

On tobacco, the application of in vitro dsCP $(657 \mathrm{bp})$ conferred a much lower level of protection (ca. 10\%) in comparison to $35-65 \%$ protection observed with the application of in vitro ds $2 \mathrm{~b}$ (336 bp); the combination of both in vitro dsRNAs did not result in higher levels of protection likely because the in vitro $\mathrm{dsCP}$ molecules exhibited very low protective effects. The two selected target genes are encoded by different genomic RNAs of CMV, which accumulate at different levels with the RNA3 and RNA4 carrying the CP sequence being much more abundant than the RNA2 carrying the $2 \mathrm{~b}$ sequence. The threshold levels of the inducer dsRNAs may depend on the target RNA levels in the host cell cytoplasm that are key for the exhibition of PTGS. Degradation of low abundance target RNAs triggered by dsRNA treatment may have a greater effect in the final outcome of RNAi. Furthermore, the function of the protein encoded by the targeted RNA could also affect the protective effect. In order to clearly identify the reason for this difference one has to study the number of efficient siRNA molecules produced by the two dsRNAs [52].

Interestingly, the level of protection obtained by the application of in vivo dsCP was much higher (ca. 85\%) than that of the in vitro dsCP (ca. 10\%), and was even comparable to that of in vivo ds $2 \mathrm{~b}(40-75 \%)$. Furthermore, the application of a mixture of the two in vivo produced dsRNA molecules showed the highest protection efficiency $(80-100 \%)$, a percentage that is extremely attractive. The difference in protection efficiency between in vitro and in vivo produced dsRNA molecules was mainly observed for those derived from the $\mathrm{CP}$ gene, which were designed over a longer sequence $(657 \mathrm{bp})$ than the dsRNA molecules derived from the $2 \mathrm{~b}$ gene $(336 \mathrm{bp})$. It is possible that the in vivo produced 
dsRNA molecules may contain not only the expected full-length dsRNA molecules, but also shorter than expected dsRNA molecules due to aberrant transcription or degradation by nucleases in the bacterial cells. Indeed, bacterial expression of dsRNAs resulted in the production of several shorter dsRNAs in addition to the main expected product of 657 bp (Supplementary Figure S2). These shorter molecules may confer a higher level of protection and should be further investigated. In RNAi transgenic plants, both short and long dsRNA constructs were found to be protective; notably accumulation of transgenederived 24-nt siRNAs coincided with higher levels of resistance and even total immunity to viral infection (reviewed in [10]). In the case of exogenous dsRNA application, it is possible that the cellular uptake of the different length molecules may also be a crucial factor for dsRNA's bioactivity. Furthermore, Tabein et al. [46] suggested that the choice of the viral region targeted by dsRNAs is crucial to induce resistance, on the basis of their bioassay results showing that from two dsRNAs of similar size targeting the N and NSm genes of Tomato spotted wilt virus, respectively, only that silencing the $N$ gene had a protective impact on N. benthamiana and tomato plants.

Overall, in our study, the application of the dsRNA molecules simultaneously with $\mathrm{CMV}$ on tobacco plants conferred a delay in symptom development. A bioassay involving application of in vitro ds2b showed that the percentage of asymptomatic plants at $7 \mathrm{dpi}$ was $77 \%$ or $18 \%$, with or without ds $2 \mathrm{~b}$ application, respectively, and at $14 \mathrm{dpi}$ at $62 \%$ or $0 \%$, respectively. The attempt to apply the in vivo dsCP molecules, which had shown the highest protection efficiency, four days before CMV inoculation, as a preventive action, showed that the protective effect was maintained, although at a lower level (35\%) in comparison to the $65 \%$ observed when the dsRNA molecules were applied simultaneously to CMV inoculum. In addition, no therapeutic action was observed when the dsRNA molecules were applied four days after CMV inoculation. The maintenance of the protective effect of the applied dsRNA molecules has been documented in studies with other plants viruses. DsRNA targeting HC-Pro and CP genes of ZYMV conferred protection at least for 20 dpi [44], while dsRNA targeting the RP gene of PMMoV conferred resistance up to $70 \mathrm{dpi}$ [13]. Several other studies on foliar application of dsRNAs to induce host resistance against a series of plant viruses have been performed, as reviewed recently by Dubrovina et al. [53].

Our study also confirmed sequence specificity of the dsRNA molecules since the topical application of in vivo ds $2 \mathrm{~b}$ on tobacco plants, which were challenged with unrelated viruses lacking a $2 \mathrm{~b}$ homologue, i.e., TMV, TRV, and PVY, did not confer any resistance. In addition, the $808 \mathrm{bp}$ dsMalE non-homologous to CMV did not confer any resistance in tobacco plants against CMV. Specificity of the dsRNA molecules is a crucial parameter when considering the induced RNAi as a prospective tool to control plant viral diseases. It is important within the crop plant itself but also towards exposed non-target organisms, e.g., beneficial insects and mammals. As research data accumulate proving successful control cases of pests and pathogens employing RNAi in agriculture, there is also a growing need to assess possible associated off-target risks [54-61].

Using C. quinoa plants in a local lesion assay, we found a significant decrease in the number of developed necrotic spots when the dsRNA molecules were applied together with CMV, suggesting that dsRNA treatment interferes with local spread of viral infection. Very early effects of dsRNA molecules to resistance were documented in tobacco-TMV interaction, with in vitro dsRNA for p126 gene counteracting the proteomic changes of tobacco induced by TMV infection as early as $15 \mathrm{~min}$ post infection [62]. Interestingly, in the present study, only low amounts of virus-derived siRNAs were detected in systemic leaves of tobacco plants exhibiting phenotypic resistance to CMV at $21 \mathrm{dpi}$, which may suggest that, upon treatment with dsRNA, the virus had not replicated efficiently in the treated cells to be able to efficiently move from cell to cell and systemically within the plant. Our deep sequencing analysis of viral siRNAs in systemic leaves of CMV-infected vs. dsRNA treated plants revealed that dsRNA treatment not only dramatically reduces the number of virus-derived siRNAs but also alters their size class profile in that 22-nt 
and 21-nt siRNAs become equally represented. This suggests that dsRNA treatment may boost production of 22-nt viral siRNAs. In Arabidopsis plants infected with CMV or other RNA viruses, DCL4, generating the 21-nt siRNAs, plays a primary role in antiviral defense, while DCL2, generating the 22-nt siRNAs, is a secondary dicer that takes over the antiviral defense when DCL4 is absent or inactivated [17,42,43]. It remains to be investigated if exogenous dsRNA treatment could induce DCL2 activity locally in the treated leaf tissues and systemically in non-treated leaves.

In the present study, we obtained data supporting the protection efficacy of the 'RNA vaccination' approach against CMV, one of the most destructive plant viruses, by applying dsRNA molecules directly onto crop and model plants. More research work is needed to optimize the delivery of the dsRNA molecules to host-plants, e.g., by conjugating them on matrices functioning as dsRNA carriers through the plant cell walls. Such novel matrices have already been developed including cell-penetrating peptides [63], clay nanosheets [14,51], cationic fluorescence nanoparticles [64] and DNA nanostructures [65]. In addition, testing the efficiency of dsRNA molecules under field conditions (e.g., [66]), where plants would be naturally infected, would provide strongest evidence on the feasibility of the approach that the small-scale bioassays performed in the present study have shown. It is important to note that RNA vaccination method was found applicable to aphid-transmitted virus [67]. Last but not least, addressing biosafety issues raised by such a biotechnological approach would reduce current uncertainties and contribute to the acceptance of this novel disease and pest control strategy.

\section{Materials and Methods}

\subsection{Virus Isolate, Bacterial Strains, and Plant Material}

CMV-G2, a Hellenic isolate of CMV, obtained from a tomato plant (Solanum lycopersicum L.) exhibiting extreme leaf malformation and mottle, which was collected during a serious CMV disease outbreak in the area of Gastouni-Olympia (Greece) in 1998 [20], was used in this study. The isolate was preserved as dried tobacco leaf samples in $\mathrm{CaCl}_{2}$ and propagated in tobacco (Nicotiana tabacum) cv. Xanthi when needed.

The bacterial strain used for the in vivo production of dsRNA molecules was the E. coli strain HT115 (DE3), which has the RNase III gene disrupted by a Tn10 transposon carrying a tetracycline-resistance marker, as well as an IPTG-inducible T7 RNA polymerase gene contained within a stable insertion of a modified lambda prophage $\lambda$ DE3 [68]. For all other molecular biology manipulations, the E. coli strains Mach1 (Invitrogen, Carlsbad, CA, USA) or $\mathrm{DH} 5 \alpha$ were used.

The bioassays were performed on $N$ tabacum cv. 'Xanthi' and Chenopodium quinoa plants. Seeds were sown and young plantlets at the stage of two leaves were transplanted in 8 -cm-diameter pots. Plants were placed in a growth chamber with constant environmental conditions (temperature/photoperiod: $24^{\circ} \mathrm{C}$ for $14 \mathrm{~h}$ of light and $18^{\circ} \mathrm{C}$ for $10 \mathrm{~h}$ dark).

\subsection{Construction of the Target DNA Templates for Transcription}

The primers and the corresponding PCR temperature profiles used in this study are shown in Table 1. To obtain the template DNA molecules for dsRNA production, total nucleic acids were extracted from tobacco artificially infected with CMV-G2, as described by Sclavounos et al. [20]. RT-PCRs were performed to obtain a cDNA fragment (ca. $850 \mathrm{bp}$ ) containing the CP gene with flanking regions and a cDNA fragment ( $c a .500 \mathrm{bp}$ ) containing the $2 \mathrm{~b}$ gene with flanking regions. In specific, first strand $\mathrm{cDNA}$ was obtained using 90 pmoles of primer (the $5^{\prime} \mathrm{CP}$ primer for the cDNA fragment containing the $\mathrm{CP}$ gene or the CMV-2b-For2 primer for the cDNA fragment containing the $2 b$ gene), 200 units of MMuLV Reverse transcriptase (New England BioLabs, Ipswich, MA, USA) and $0.9 \mu \mathrm{g}$ of total nucleic acids as template, in a $20 \mu \mathrm{L}$ reaction. Then, $1 \mu \mathrm{L}$ of the produced first strand cDNA was amplified in a $50 \mu \mathrm{L}$ reaction using the proofreading Vent DNA Polymerase (New England BioLabs, Ipswich, MA, USA) and $0.2 \mu \mathrm{M}$ of $5^{\prime} \mathrm{CP} / 3^{\prime} \mathrm{CP}$ primers for the fragment containing the CP gene or CMV-2b-For2/CMV-2b-Rev primers for the fragment containing 
the $2 \mathrm{~b}$ gene. The above two RT-PCR products were cloned into pCRIITopo (Invitrogen, Carlsbad, CA, USA) and transformed into E. coli Mach 1 Topo cells (Invitrogen, Carlsbad, CA, USA). The resulting plasmid constructs: pCRIITopo::CMV-CP 850 and pCRIITopo::CMV$2 \mathrm{~b}_{500}$ were confirmed by colony PCR and digestion with EcoRI.

Table 1. Primers and PCR conditions used in this study.

\begin{tabular}{|c|c|c|c|}
\hline Name of Primer & Sequence $5^{\prime}$ to $3^{\prime}$ & PCR Thermal Profile & Reference \\
\hline $5^{\prime} \mathrm{CP}$ & CTCGAATTCGGATCCGCTTCTCCGCGAG & \multirow{2}{*}{$\begin{array}{l}\left(94^{\circ} \mathrm{C} \text { for } 3 \mathrm{~min}\right) \times 1 \text { cycle, }\left(94^{\circ} \mathrm{C}\right. \\
\text { for } 1 \mathrm{~min}, 50{ }^{\circ} \mathrm{C} \text { for } 1 \mathrm{~min}, 72{ }^{\circ} \mathrm{C} \\
\text { for } 1 \mathrm{~min}) \times 35 \text { cycles, }\left(72{ }^{\circ} \mathrm{C} \text { for }\right. \\
10 \mathrm{~min}) \times 1 \text { cycle }\end{array}$} & [69] \\
\hline $3^{\prime} \mathrm{CP}$ & GGCGAATTCGAGCTCGCCGTAAGCTGGATGGAC & & {$[69]$} \\
\hline CMV-2b-For2 & AGGGTTGAGCGTGTAAATTCC & \multirow[b]{2}{*}{$\begin{array}{l}\text { As with } 5^{\prime} \mathrm{CP} / 3^{\prime} \mathrm{CP} \\
\text { oligonucleotides }\end{array}$} & This work \\
\hline CMV-2b-Rev & $\begin{array}{c}\text { CCGT(AT) } \\
\text { AGCTGGATGGACAACC }\end{array}$ & & This work \\
\hline CMV-CP-LIT-For * & GCGGAATTCTCATGGACAAATC & \multirow{2}{*}{$\begin{array}{l}\left(94^{\circ} \mathrm{C} \text { for } 5 \mathrm{~min}\right) \times 1 \text { cycle, }\left(94^{\circ} \mathrm{C}\right. \\
\text { for } 1 \mathrm{~min}, 65^{\circ} \mathrm{C} \text { for } 1 \mathrm{~min}, 72^{\circ} \mathrm{C} \\
\text { for } 1 \mathrm{~min}) \times 35 \text { cycles, }\left(72^{\circ} \mathrm{C} \text { for }\right. \\
10 \mathrm{~min}) \times 1 \text { cycle }\end{array}$} & This work \\
\hline CMV-CP-LIT-Rev * & GCGGGATCCGTTCAAACTGG & & This work \\
\hline $\mathrm{T} 7$ & TAATACGACTCACTATAGG & $\begin{array}{c}\left(94{ }^{\circ} \mathrm{C} \text { for } 3 \mathrm{~min}\right) \times 1 \text { cycle, }\left(94^{\circ} \mathrm{C}\right. \\
\text { for } 30 \mathrm{sec}, 50{ }^{\circ} \mathrm{C} \text { for } 30 \mathrm{sec}, 72{ }^{\circ} \mathrm{C} \\
\text { for } 30 \mathrm{sec}) \times 25 \text { cycles, }\left(72{ }^{\circ} \mathrm{C} \text { for } 5\right. \\
\min ) \times 1 \text { cycle }\end{array}$ & New England Biolabs \\
\hline CMV-CP-F-Linker ** & GGGGATCCATGGACAAATCTGAATC & \multirow{2}{*}{$\begin{array}{c}\left(98^{\circ} \mathrm{C} \text { for } 30 \mathrm{sec}\right) \times 1 \text { cycle, }\left(98^{\circ} \mathrm{C}\right. \\
\text { for } 10 \mathrm{sec}, 60{ }^{\circ} \mathrm{C} \text { for } 30 \mathrm{sec}, \\
\left.72{ }^{\circ} \mathrm{C} \text { for } 30 \mathrm{sec}\right) \times 35 \text { cycles, }(72 \\
\left.{ }^{\circ} \mathrm{C} \text { for } 10 \mathrm{~min}\right) \times 1 \text { cycle }\end{array}$} & This work \\
\hline $\begin{array}{l}\text { CMV-CP-R- } \\
\text { Linker ** }\end{array}$ & GGGGATCCTCAAACTGGGAGCAC & & This work \\
\hline CMV-2b-F-Linker ** & GGGGATCCATGGAATCGAACGAAG & \multirow{2}{*}{$\begin{array}{l}\left(98^{\circ} \mathrm{C} \text { for } 30 \mathrm{sec}\right) \times 1 \mathrm{cycle},\left(98^{\circ} \mathrm{C}\right. \\
\text { for } 10 \mathrm{sec}, 62^{\circ} \mathrm{C} \text { for } 30 \mathrm{sec}, 72{ }^{\circ} \mathrm{C} \\
\text { for } 1 \mathrm{~min}) \times 35 \text { cycles, }\left(72{ }^{\circ} \mathrm{C} \text { for }\right. \\
10 \mathrm{~min}) \times 1 \mathrm{cycle}\end{array}$} & This work \\
\hline CMV-2b-R-Linker ** & GGGGATCCTCAAAACGCACCTTC & & This work \\
\hline EcoRI-T7-Linker- BamHI *\# & GAGAATTCTAATACGACTCACTATAGG $\underline{\text { GGATCC }}$ & $\begin{array}{l}\left(98^{\circ} \mathrm{C} \text { for } 30 \mathrm{sec}\right) \times 1 \mathrm{cycle},\left(98^{\circ} \mathrm{C}\right. \\
\text { for } 10 \mathrm{sec}, 55^{\circ} \mathrm{C} \text { for } 30 \mathrm{sec}, 72{ }^{\circ} \mathrm{C} \\
\text { for } 30 \mathrm{sec} \times 35 \text { cycles, }\left(72{ }^{\circ} \mathrm{C} \text { for }\right. \\
10 \mathrm{~min}) 1 \mathrm{cycle}\end{array}$ & This work \\
\hline pUC/M13 Forward & CGCCAGGGTTTTCCCAGTCACGAC & \multirow{2}{*}{$\begin{array}{l}\left(94^{\circ} \mathrm{C} \text { for } 5 \mathrm{~min}\right) \times 1 \mathrm{cycle},\left(94^{\circ} \mathrm{C}\right. \\
\text { for } 1 \mathrm{~min}, 55^{\circ} \mathrm{C} \text { for } 1 \mathrm{~min}, 72^{\circ} \mathrm{C} \\
\text { for } 1 \mathrm{~min}) \times 35 \text { cycles, }\left(72^{\circ} \mathrm{C} \text { for }\right. \\
10 \mathrm{~min}) \times 1 \mathrm{cycle}\end{array}$} & General primer \\
\hline pUC/M13 Reverse & AGCGGATAACAATTTCACACAGGA & & General primer \\
\hline
\end{tabular}

${ }^{*}$ The EcoRI restriction site (GAATTC) is underlined, and the BamHI restriction site (GGATCC) is bold and underlined. ${ }^{* *}$ The Linker sequence is written in bold \# The T7 promoter sequence is written in italics.

For the in vivo transcription, two plasmid constructs were prepared: (a) one to produce dsRNA of a CP gene fragment ( $657 \mathrm{bp})$, and $(\mathrm{b})$ one to produce dsRNA of $2 \mathrm{~b}$ gene (336 bp): (a) The $657 \mathrm{bp}$ fragment of CMV-G2 CP gene was amplified with primers CMVCP-LIT-For and CMV-CP-LIT-Rev from plasmid pCRIITopo::CMV-CP 850 (Supplementary Figure S1.i. step 1). The PCR product was gel excised, cloned into the pCRIITopo plasmid vector, and transformed into E. coli Mach 1 cells. The resulting plasmid construct pCRIITopo::CMV-CP 657 was confirmed by EcoRI restriction digest, PCR with M13F/M13R primers and CMV-CP-LIT- For/CMV-CP-LIT-Rev primers (Supplementary Figure S1.i. steps 2,3$)$. The $\mathrm{CP}$ gene fragment was then excised by restriction digest with EcoRI and BamHI, gel purified, cloned in the plasmid cloning vector LITMUS28i (New England BioLabs, Ipswich, MA, USA) similarly digested with EcoRI and BamHI, and transformed into E. coli DH5a cells. The resulting plasmid construct pLITMUS28i::CMV-CP 657 was confirmed by restriction digest with EcoRI and BamHI, colony PCR with CMV-CP-LITFor/CMV-CP-LIT-Rev and T7 primers (Supplementary Figure S1.i. steps 4, 5, 6). (b) The CMV-G 2b gene (336 bp) was amplified using the primers CMV-2b-F- Linker and CMV2b-R-Linker from plasmid pCRIITopo::CMV-2b $b_{500}$ (Supplementary Figure S1.ii. steps 1, 2). The PCR product was gel purified, and $1 \mu \mathrm{L}$ of a 1:100 dilution of this purified PCR product was amplified with EcoRI-T7-Linker-BamHI primer (Supplementary Figure S1.ii. steps 3,4). This PCR product was digested with NcoI and BamHI, ligated into plas- 
mid cloning vector LITMUS28i (New England Biolabs, Ipswich, MA, USA) similarly digested with the same enzymes and transformed into E. coli DH5a cells. The plasmid construct pLITMUS28i::2 $\mathrm{b}_{336}$ was confirmed by colony PCR with primers M13F/M13R and EcoRI-T7-Linker-BamHI primer (Supplementary Figure S1.ii. steps 5a, 6). The plasmid constructs pLITMUS28i::CMV-CP 657 and pCRIITopo::CMV-2b $\mathrm{b}_{501}$ were confirmed also by sequencing. The plasmid pLITMUS28iMal (New England Biolabs, Ipswich, MA, USA) was used as control plasmid. This plasmid carries the $808 \mathrm{bp}$ BglII-EcoRI fragment of pMal-p2 vector (New England Biolabs, Ipswich, MA, USA) i.e., a non-functional portion of the maltose/maltodextrin-binding periplasmic protein encoding gene of $E$. coli (malE gene) with no sequence similarity with CMV. The three above plasmid constructs pLITMUS28i::CMV-CP ${ }_{657}$, pLITMUS28i::2 $b_{336}$, and pLITMUS28iMal were transformed into competent $E$. coli $\mathrm{HT} 115$ (DE3) cells, prepared using the $\mathrm{CaCl}_{2}$ method [70], in order to be used for the in vivo production of dsRNA (Supplementary Figure S1.i. step 7 and Figure S1.ii. step 7).

For the in vitro transcription, two DNA templates were prepared in order to produce dsRNA of: (a) a $657 \mathrm{bp}$ fragment of $\mathrm{CP}$, and (b) the $2 \mathrm{~b}$ gene ( $336 \mathrm{bp}$ ), all containing a T7 RNA polymerase promoter at the $5^{\prime}$ ends of both strands. Both DNA templates were prepared by a two-step PCR approach (Supplementary Figure S1.ii. steps 1 to 5b, Figure S1.iii.). The 1st PCR was performed with the primers corresponding to the targeted gene and the respective plasmid DNA template shown in Table 2. The PCR products were separated by $1.5 \%(w / v)$ agarose gel electrophoresis and gel purified. The 2nd PCR step was performed with primer EcoRI-T7- Linker-BamHI, and $1 \mu \mathrm{L}$ of 1:100 gel purified PCR product from 1 st PCR as DNA template. The PCR products were separated by $1.5 \%(w / v)$ agarose gel electrophoresis, gel purified, and used as DNA templates for in vitro transcription.

Table 2. Primer pairs and PCR conditions used to generate DNA templates for in vitro transcription.

\begin{tabular}{|c|c|c|}
\hline $\begin{array}{l}\text { DNA Template for In Vitro } \\
\text { Transcription }\end{array}$ & $\begin{array}{c}\text { Primer Pair Used in 1st Step } \\
\text { PCR }\end{array}$ & $\begin{array}{c}\text { DNA Template Used in the } \\
\text { 1st PCR * }\end{array}$ \\
\hline $\mathrm{CP}$ fragment of $657 \mathrm{bp}$ & $\begin{array}{l}\text { CMV-CP-F-Linker } \\
\text { CMV-CP-R-Linker }\end{array}$ & pCRIITopo::CP 657 \\
\hline $2 b(336 b p)$ & $\begin{array}{l}\text { CMV-2b-F-Linker } \\
\text { CMV-2b-R-Linker }\end{array}$ & pCRIITopo::2 $b_{500}$ \\
\hline
\end{tabular}

* The lower script refers to the length of the cloned fragment, i.e., in pCRIITopo:: $\mathrm{CP}_{657}$ means a $657 \mathrm{bp}$ fragment of the $\mathrm{CP}$ gene; in pCRIITopo:: $2 \mathrm{~b}_{500}$ means a fragment of $500 \mathrm{bp}$ containing the $2 \mathrm{~b}$ gene with flanking regions.

\subsection{Production of dsRNA Molecules}

In vitro and in vivo approaches were used for the production of dsRNA molecules for exogenous application in plants [41].

\subsubsection{In Vivo dsRNA Production}

E. coli HT115(DE3) cells transformed with one of the plasmid constructs: pLITMUS28i: :CMV-CP 657, pLITMUS28i::2b $\mathrm{b}_{336}$ or pLITMUS28i::Mal, were used for production of dsRNA molecules, as described previously by Tenllado et al. [13] with minor modifications [41]. Briefly, single colonies of E. coli HT115(DE3) transformants containing any one of the three above plasmid constructs were grown with shaking at $37^{\circ} \mathrm{C}$ for $16 \mathrm{~h}$ in LB supplemented with tetracycline at $12.5 \mu \mathrm{g} / \mathrm{mL}$ and ampicillin at $100 \mu \mathrm{g} / \mathrm{mL}$. Each culture was then diluted 1:100 to a final volume of $4.5 \mathrm{~L}$ of LB supplemented with the same antibiotics, allowed to grow at $37^{\circ} \mathrm{C}$ to $\mathrm{OD}_{595}=0.5$, and then supplemented with IPTG to induce T7 polymerase for an additional $2 \mathrm{~h}$. The final cell concentration obtained was $\mathrm{OD}_{595}=1.25$. Total nucleic acids were extracted from the bacterial cells of the above cultures by a phenol-chloroform extraction method and ethanol precipitation. The nucleic acids pellet was resuspended in $2.7 \mathrm{~mL}$ of DEPC-treated water and used for the plant assays. 


\subsubsection{In Vitro dsRNA Production}

The in vitro transcription reactions were set up using the T7 RiboMAX ${ }^{\mathrm{TM}}$ Express RNAi System (Promega, Madison, WI, USA) and appx. $0.7 \mu \mathrm{g}$ of one of the two PCRgenerated DNA templates described above, derived from the $\mathrm{CP}(657 \mathrm{bp})$ and $2 \mathrm{~b}(336 \mathrm{bp})$ genes, following manufacturer's instructions. Incubation of the reactions at $37^{\circ} \mathrm{C}$ was allowed for $3 \mathrm{~h}$. The reactions were subsequently placed at $85{ }^{\circ} \mathrm{C}$ and left to slowly cool down to room temperature overnight. For confirmation by gel analysis, $1 \mu \mathrm{L}$ of the transcription reactions was electrophoresed on $1.5 \%$ agarose gel.

Both the in vitro and in vivo produced RNAs were treated with DNase and RNase provided with the T7 RiboMAX ${ }^{\mathrm{TM}}$ Express RNAi System (Promega) in $2 x \mathrm{xSC}$ buffer at $37^{\circ} \mathrm{C}$ for $1 \mathrm{~h}$ to confirm quality and quantity of produced dsRNA of the targeted sequences. The treated dsRNA was submitted to standard phenol-chloroform-isoamyl alcohol purification, ethanol precipitation, and resuspension in the same volume of DEPC-treated water. The purified dsRNA was analyzed by electrophoresis on $1.5 \%$ agarose gel. The results are summarized in Supplementary Figure S2.

\subsection{Plant Bioassays}

\subsubsection{Bioassay on Tobacco}

The bioassays were performed on tobacco ( $N$. tabacum cv. 'Xanthi') plantlets at the stage of two true leaves in order to evaluate the protective effect against CMV infection of the dsRNA molecules produced in vitro or in vivo in this study. The CMV inoculum used in the bioassays was obtained from CMV-G2-infected N. tabacum plants [20], by grinding $0.5 \mathrm{~g}$ of young CMV-infected leaf tissue at 15 days post inoculation (dpi) in $2 \mathrm{~mL}$ DEPCtreated sterile distilled water, followed by a dilution of $1 / 50 \mathrm{v} / \mathrm{v}$ for application onto the plants. The plants were treated with CMV inoculum or CMV inoculum in mixture with one or both of the dsRNA molecules $(\mathrm{ds} 2 \mathrm{~b}, \mathrm{dsCP})$ produced in vitro or in vivo in this study. Application of these mixtures onto plants was performed by rubbing a carborundumdusted leaf surface with $10 \mu \mathrm{L}$ of the respective mixture $(8 \mu \mathrm{L}$ of $1 / 50 v / v$ dilution of CMV inoculum with $2 \mu \mathrm{L}$ of dsRNA preparations (12-16 $\mu \mathrm{g}$ in vitro dsCP or in vitro ds $2 \mathrm{~b}$ or in vivo ds2b; 0.4-1.2 $\mu \mathrm{g}$ in vivo dsCP) per leaf. Symptom development was recorded at 7 and 14 dpi. Each topical application treatment was applied onto 20 plants, with two leaves per plant treated. Three independent replicates of the bioassay were performed per treatment. The negative controls used included: (a) sterile distilled water instead of CMV inoculum, and (b) in vivo produced dsMalE in mixture with CMV inoculum. In all bioassays, plants treated only with CMV were used as control to assess infectivity of the viral inoculum used. In all bioassays, plants treated only with CMV were used as control to assess infectivity of the viral inoculum used. Inoculated plants were maintained for 21 days in a growth chamber under insect proof conditions at $22{ }^{\circ} \mathrm{C}$ day / night temperatures and $16 \mathrm{~h}$ daylight. Plants were monitored for symptom development at 7 and $14 \mathrm{dpi}$.

A bioassay was also performed on N. tabacum plants to monitor the time needed for symptom development upon CMV infection in the presence or not of dsRNA molecules. In specific, 11 plants were treated with CMV inoculum and 13 plants with CMV inoculum in mixture with in vitro produced ds2b. Symptom development was recorded at 7, 14, and $19 \mathrm{dpi}$.

The protective action of the dsRNA molecules when applied on N. tabacum plants with a four-day difference to CMV inoculation was also investigated. To this end, the in vivo produced dsCP was applied simultaneously or four days before, or four days after CMV inoculation, and symptom development was monitored for $15 \mathrm{dpi}$. Each treatment was applied to 20 plants, with two leaves per plant treated.

The specificity of the in vivo produced ds $2 \mathrm{~b}$ was investigated using a non-cognate viral inoculum, namely TMV, PVY, and TRV prepared similarly to CMV. Specifically, tobacco plants were treated with: (a) CMV inoculum (20 plants), and (b) in vivo produced ds $2 \mathrm{~b}$ in mixture with TMV, PVY, or TRV inoculum (20 plants per dsRNA-virus combination). 
The percentage of CMV-infected plants in the bioassays was determined at $14 \mathrm{dpi}$, unless otherwise mentioned, by symptom evaluation and ELISA testing (Cucumber mosaic virus DTL complete kit, LOEWE $^{\circledR}, \mathrm{DE}$ ) (data not shown).

\subsubsection{Bioassay on Chenopodium Quinoa Plants}

The CMV inoculum used in the bioassay was obtained from CMV-G2-infected N. tabacum plants as described above, and its $1 / 10 v / v$ dilution in DEPC-treated sterile distilled water was used for artificial inoculation of C. quinoa plants, a local lesion host of CMV. Ten leaves were used in total per treatment (five leaves per plant). Each leaf received $10 \mu \mathrm{L}$ $\mathrm{CMV}$ inoculum or CMV inoculum in mixture with in vitro dsCP or in vitro ds $2 \mathrm{~b}$ or their combination, as described above for bioassays on tobacco. The plants were kept at $21^{\circ} \mathrm{C}$ and the local leaf necrotic lesions due to viral infection were counted at $6 \mathrm{dpi}$.

\subsubsection{Small RNA Blot Hybridization Analysis}

The method applied in this study for detection of viral siRNAs in N. tabacum plants treated with CMV or CMV in mixture with in vivo dsRNA molecules, had been previously developed at Institute of Botany in University of Basel (Switzerland) for other plant-virus pathosystems [71-73]. Total RNA was extracted from: (a) the 3rd leaf of mock inoculated tobacco plants (healthy plants); (b) a pool of leaves from plants inoculated with CMV exhibiting symptoms; (c) the 2nd, 3rd, and 4th leaf of a plant co-inoculated with CMV and in vivo dsCP, not showing symptoms; (d) the 3rd leaf of a plant co-inoculated with CMV and in vivo ds2b, not showing symptoms. All leaves were collected at $21 \mathrm{dpi}$, frozen in liquid nitrogen and stored at $-80{ }^{\circ} \mathrm{C}$. For each of the above cases, the total RNA extraction was performed twice, using each time $1 \mathrm{~g}$ of leaf tissue and the mirVana ${ }^{\mathrm{TM}}$ miRNA isolation kit (Ambion, Austin, TX, USA), following the manufacturer's protocol. All extracts were analyzed separately. The total RNA extracts were quantified by a UV-Vis spectrophotometer (NanoDrop, Thermo Scientific, Waltham, MA, USA). The samples were analyzed on a $15 \%$ polyacrylamide gel (19:1 ratio of acrylamide to bis-acrylamide, $8 \mathrm{M}$ urea). The gel was run at $350 \mathrm{~V}$ for about $4 \mathrm{hrs}$ and then stained with ethidium bromide to evaluate the integrity and the amount of the loaded RNA (Figure 5). The RNA was then transferred from the gel to a Hybond $\mathrm{N}^{+}$nylon membrane by overnight electroblotting. Blot hybridization was performed overnight at $35^{\circ} \mathrm{C}$ using one of the four DNA probes listed in Table 3 and standard procedures. The probes were end-labeled with ${ }^{32} \mathrm{P}$ using the Polynucleotide Kinase (Roche, Penzberg, Germany) and purified through spin columns containing Sephadex ${ }^{\mathrm{TM}}$ G-25 DNA grade F resin (MicroSpin ${ }^{\mathrm{TM}}$ G25 columns, GE Healthcare, Chicago, IL, USA), following the manufacturer's recommendations. Depending on the applied probe, the signal was detected after 1 to 6 days exposure of a storage phosphor screen (GE Healthcare, Chicago, IL, USA) to the membrane, which was then scanned using a radioisotopic imaging system (Molecular Imager, BioRad, Hercules, CA, USA).

Table 3. DNA probes used for RNA blot hybridization.

\begin{tabular}{clc}
\hline Name of the Probe & \multicolumn{1}{c}{$\begin{array}{c}\text { Sequence } \\
\left(\mathbf{5}^{\prime} \text { to } \mathbf{3}^{\prime} \mathbf{)}\right.\end{array}$} & $\begin{array}{c}\text { Number of } \\
\text { Nucleotides }\end{array}$ \\
\hline Cmv1_3169_s* & TCCATCCAGCTTACGGCTAAAATG & 24 \\
Cmv1_3187_as* & GATTTCTCCACGACTGACCATTTT & 24 \\
Cmv1_171_s & GTTGATAAGACAGCTCATGAGCAGC & 25 \\
miR160a_as & TGGCATACAGGGAGCCAGGCA & 21 \\
\hline${ }^{*}$ s = sense, as = antisense. & &
\end{tabular}

The probes were designed based on Illumina sequencing data from the exact same RNA samples, acquired through collaboration with Fasteris SA (www.fasteris.com, Geneva, CH (accessed on 19 March 2021)) (see below). Two probes (Cmv1_3169_s and Cmv1_3187_as; $24 \mathrm{nt}$ ) are specific for 'hot spots' (a region that serves as a preferential source of siRNA production) in sense and antisense polarity on RNA1 and the other one (Cmv1_171_s; 25 nt) 
for the 'cold' spot on the same RNA1. As a loading control, a $21 \mathrm{nt}$ probe was employed that hybridizes to and detects the evolutionarily conserved plant miRNA miR160.

\subsubsection{Illumina Sequencing and Bioinformatics Analysis of Viral siRNAs}

Total RNA samples from systemic leaves of the representative mock-inoculated healthy (GLY-1), CMV-infected (GLY-2) and in vivo dsCP treated (GLY-3) N. tabacum plants described above were selected for library preparation and Illumina small RNA sequencing using TruSeq ${ }^{\mathrm{TM}}$ SBS v5 kit and Genome Analyzer HiSeq 2000, respectively, at Fasteris SA. All the three libraries were bar-coded and sequenced in one lane of the HiSeq2000, yielding $19^{\prime} 002^{\prime} 747$ (GLY-1), 22'658'565 (GLY-2), and 19'195'087 (GLY-3) reads. Following adapter trimming and low quality read removal, 20-25 nucleotide reads were mapped (MAQ) to the reference sequences of CMV RNA1 (NCBI Genbank accession CMU20220), RNA2 (CMU20218), and RNA3 (CMU20219), with up to 2 mismatches and counted based on size $(20,21,22,23,24,25$, total 20-25 nt) and polarity (forward, reverse, total) using in-house Fasteris scripts to create single-nucleotide resolution maps of viral siRNAs. The resulting maps were transferred to Excel and further processed to create graphs and histograms shown in Figure 6.

\section{Conclusions}

This study presents the application of RNA vaccination in N. tabacum and C. quinoa against $\mathrm{CMV}$, a virus with the largest host range. DsRNA molecules for the $\mathrm{CP}$ and $2 \mathrm{~b}$ genes of CMV protected tobacco upon their topical application onto leaf surfaces. DsCP exhibited a four-day protective effect but no therapeutic effect was observed. The in vivo-produced $\mathrm{dsCP}$ was more efficient than the in vitro-produced dsCP which unexpectedly showed the smallest protective effect. In vitro ds $2 \mathrm{~b}$ was found to be more efficacious than in vitro dsCP. Deep small RNA sequencing analysis revealed that systemic leaves of dsCP treated plants accumulated low amounts of virus-derived siRNAs with an altered ratio of 21- and 22-nt size classes, suggesting that dsRNA treatment may boost the antiviral activity of DCL2.

Supplementary Materials: The following are available online at https:/ /www.mdpi.com/article/10 .3390/plants10050963/s1, Figure S1: Schematic representation of the methods for in vivo and in vitro production of dsRNA, Figure S2: Production of dsRNA molecules to be used for topical application in the bioassays., Figure S3: In vitro dsRNA-CP and in vitro dsRNA-2b provide protection against $\mathrm{CMV}$ in a local lesion assay.

Author Contributions: M.C.H. and A.S. produced the dsRNA molecules and performed the bioassays; R.R. performed the RNA blot hybridization; M.M.P. analyzed Illumina sequencing data, prepared Figure 5, designed the probes for RNA blot hybridization, and wrote parts of the manuscript describing viral siRNAs; A.E.V. designed and supervised the present research work; M.C.H., A.S., M.M.P., R.R. and A.E.V. contributed in writing and editing the final manuscript. All authors have read and agreed to the published version of the manuscript.

Funding: This research was performed in the frame of the project PYTHAGORAS II (MIS 99832) funded by the General Secretariat of Research and Technology (GSRT) of Greece, and of the COST Action FA0806 "Plant virus control employing RNA-based vaccines: A novel non-transgenic strategy" funded by EU.

Institutional Review Board Statement: Not applicable.

Informed Consent Statement: Not applicable.

Acknowledgments: We thank the team of Fasteris AG for Illumina sequencing and Patricia Otten for bioinformatics assistance in processing of the raw sequencing data and preparing single-nucleotide resolution maps of viral siRNAs. Authors would like to thank: (a) Andy Mavromoustakos (University of Arkansas, USA) for his assistance in statistical data analysis; (b) Christina Varveri and Nikon Vassilakos (Benaki Phytopathological Institute, Greece) for offering the TRV and PVY plant inoculum; (c) Panagiota Kyriakopoulou (Agricultural University of Athens, Greece) for offering TMV plant inoculum, providing access to laboratory facilities and her valuable advice during this research work. 
Conflicts of Interest: All authors declare no conflict of interest.

\section{References}

1. Zotti, M.; Dos Santos, E.A.; Cagliari, D.; Christiaens, O.; Taning, C.N.T.; Smagghe, G. RNA interference technology in crop protection against arthropod pests, pathogens and nematodes. Pest Manag. Sci. 2018, 74, 1239-1250. [CrossRef]

2. Csorba, T.; Kontra, L.; Burgyán, J. Viral silencing suppressors: Tools forged to fine-tune host-pathogen coexistence. Virology 2015, 479-480, 85-103. [CrossRef]

3. Bronkhorst, A.W.; van Rij, R.P. The long and short of antiviral defense: Small RNA-based immunity in insects. Curr. Opin. Virol. 2014, 7, 19-28. [CrossRef] [PubMed]

4. Csorba, T.; Pantaleo, V.; Burgyán, J. RNA silencing: An antiviral mechanism. Adv. Virus Res. 2009, 75, 35-71. [PubMed]

5. Li, Y.; Lu, J.; Han, Y.; Fan, X.; Ding, S.W. RNA interference functions as an antiviral immunity mechanism in mammals. Science 2013, 342, 231-234. [CrossRef]

6. Wang, M.B.; Metzlaff, M. RNA silencing and antiviral defense in plants. Curr. Opin. Plant Biol. 2005, 8, 216-222. [CrossRef]

7. Wang, M.B.; Masuta, C.; Smith, N.A.; Shimura, H. RNA silencing and plant viral diseases. Mol. Plant Microbe Interact. 2012, 25, 1275-1285. [CrossRef]

8. Li, F.; Wang, A. RNA-targeted antiviral immunity: More than just RNA silencing. Trends Microbiol. 2019, 27, 792-805. [CrossRef] [PubMed]

9. Kreuze, J.F.; Valkonen, J.P. Utilization of engineered resistance to viruses in crops of the developing world, with emphasis on sub-Saharan Africa. Curr. Opin. Virol. 2017, 26, 90-97. [CrossRef] [PubMed]

10. Pooggin, M.M. RNAi-mediated resistance to viruses: A critical assessment of methodologies. Curr. Opin. Virol. 2017, 26, 28-35. [CrossRef]

11. Dong, O.X.; Ronald, P.C. Genetic engineering for disease resistance in plants: Recent progress and future perspectives. Plant Physiol. 2019, 180, 26-38. [CrossRef]

12. Tenllado, F.; Diaz-Ruiz, J.R. Double-stranded RNA-mediated interference with plant virus infection. J. Virol. 2001, 75, 12288-12297. [CrossRef]

13. Tenllado, F.; Martínez-García, B.; Vargas, M. Díaz-Ruíz, J.R. Crude extracts of bacterially expressed dsRNA can be used to protect plants against virus infections. BMC Biotechnol. 2003, 3, 3. [CrossRef] [PubMed]

14. Mitter, N.; Worrall, E.A.; Robinson, K.E.; Xu, Z.P.; Carroll, B.J. Induction of virus resistance by exogenous application of double-stranded RNA. Curr. Opin. Virol. 2017, 26, 49-55. [CrossRef] [PubMed]

15. Voloudakis, A.E.; Holeva, M.C.; Kaldis, A.; Kim, D. Tools and techniques for production of double stranded RNA and its application for management of plant viral diseases. In Genes, Genetics and Transgenics for Virus Resistance in Plants; Basavaprabhu, P.L., Ed.; Caister Academic Press: Poole, UK, 2018; pp. 119-140.

16. Dalakouras, A.; Wassenegger, M.; Dadami, E.; Ganopoulos, I.; Pappas, M.; Papadopoulou, K.K. Genetically Modified OrganismFree RNA interference: Exogenous application of RNA molecules in plants. Plant Physiol. 2020, 182, 38-50. [CrossRef] [PubMed]

17. Pooggin, M.M. Small RNA-omics for plant virus identification, virome reconstruction, and antiviral defense characterization Front Microbiol. 2018, 9, 2779. [CrossRef]

18. Roossinck, M.J. Evolutionary history of Cucumber mosaic virus deduced by phylogenetic analyses. J. Virol. 2002, 76, 3382-3387. [CrossRef]

19. Jacquemond, M. Cucumber Mosaic Virus. Adv. Virus Res. 2012, 84, 439-504.

20. Sclavounos, A.P.; Voloudakis, A.E.; Arabatzis, C.; Kyriakopoulou, P.E. A severe Hellenic CMV tomato isolate: Symptom variability in tobacco, characterization and discrimination of variants. Eur. J. Plant Pathol. 2006, 115, 163-172. [CrossRef]

21. Ye, J.; Qu, J.; Zhang, J.F.; Geng, Y.F.; Fang, R.X. A critical domain of the Cucumber mosaic virus $2 b$ protein for RNA silencing suppressor activity. FEBS Lett. 2009, 583, 101-106. [CrossRef]

22. Masuta, C.; Inaba, J.; Shimura, H. The $2 \mathrm{~b}$ proteins of Cucumber mosaic virus generally have the potential to differentially induce necrosis on Arabidopsis. Plant Signal Behav. 2012, 7, 43-45. [CrossRef]

23. Gallitelli, D. The ecology of Cucumber mosaic virus and sustainable agriculture. Virus Res. 2000, 71, 9-21. [CrossRef]

24. Kyriakopoulou, P.E.; Bem, F.; Varveri, C. Tomato shrinkage and tomato fruit toughness, two new diseases in Greece, probably related to cucumber mosaic virus. Ann. Inst. Phytopathol. Benaki 1991, 16, 151-156.

25. Kyriakopoulou, P.E.; Perdikis, D.C.; Sclavounos, A.P.; Girgis, S.M.; Lycouressis, D.P.; Tsitsipis, J.A.; Christakis, P.A. Cucumber mosaic cucumovirus incidence in open-field tomato in the Olympia area and trap captures of alate aphids. Bull. OEPP 2000, 30, 305-315. [CrossRef]

26. Kyriakopoulou, P.E.; Vassilakos, N.; Bem, F.P.; Varveri, C.; Girkis, M.S.; Skopelitis, N.G. Cucumber mosaic virus in industrial tomato of Eleia county and the new threat from tomato necrosis. Phytopathol. Mediterr. 2000, 39, 330.

27. Jorda, C.; Alfaro, A.; Arranda, M.A.; Moriones, E.; Garcia-Arenal, F. An epidemic of Cucumber mosaic virus plus satellite RNA in tomatoes in eastern Spain. Plant Dis. 1992, 76, 363-366. [CrossRef]

28. Shintaku, M. Coat protein gene sequences of two Cucumber mosaic virus strains reveal a single amino acid change correlating with chlorosis induction. J. Gen. Virol. 1991, 72, 2587-2589. [CrossRef] [PubMed]

29. Shintaku, M.; Zhang, L.; Palukaitis, P. A single amino acid substitution in the coat protein of Cucumber mosaic virus induces chlorosis in tobacco. Plant Cell 1992, 4, 751-757. [PubMed] 
30. Palukaitis, P.; Garcia-Arenal, F. Cucumoviruses. Adv. Virus Res. 2003, 62, 241-323.

31. Morroni, M.; Thompson, J.R.; Tepfer, M. Twenty Years of transgenic plants resistant to Cucumber mosaic virus. Mol. Plant Microbe Interact. 2008, 21, 675-684. [CrossRef]

32. Beachy, R.N.; Loesch-Fries, S.; Tumer, N.E. Coat protein-mediated resistance against virus infection. Ann. Rev. Phytopath. 1990, 28, 451-472. [CrossRef]

33. Fuchs, M.; Provvidenti, R.; Slightom, J.L.; Gonsalves, D. Evaluation of transgenic tomato plants expressing the coat protein gene of Cucumber mosaic virus strain WL under field conditions. Plant Dis. 1996, 80, 270-275. [CrossRef]

34. Fuchs, M.; Chirco, E.M.; Gonsalves, D. Movement of coat protein genes from a commercial virus-resistant transgenic squash into a wild relative. Environ. Biosafety Res. 2004, 3, 5-16. [CrossRef] [PubMed]

35. Gielen, J.; Ultzen, T.; Bontems, S.; Loots, W.; van Schepen, A. Coat protein-mediated protection to Cucumber mosaic virus infections in cultivated tomato. Euphytica 1996, 88, 139-149. [CrossRef]

36. Jacquemond, M.; Teycheney, P.-Y.; Carrère, I.; Navas-Castillo, J.; Tepfer, M. Resistance phenotypes of transgenic tobacco plants expressing different Cucumber mosaic virus (CMV) coat protein genes. Mol. Breed. 2001, 8, 85-94. [CrossRef]

37. Kalantidis, K.; Psaradakis, S.; Tabler, M.; Tsagris, M. The occurrence of CMV-specific short RNAs in transgenic tobacco expressing virus-derived double-stranded RNA is indicative of resistance to the virus. Mol. Plant Microbe Interact. 2002, 15, 826-833. [CrossRef] [PubMed]

38. Chen, Y.-K.; Lohuis, D.; Goldbach, R.; Prins, M. High frequency induction of RNA-mediated resistance against Cucumber mosaic virus using inverted repeat constructs. Mol. Breed. 2004, 14, 215-226. [CrossRef]

39. Muhammad, T.; Zhang, F.; Zhang, Y.; Liang, Y. RNA interference: A natural immune system of plants to counteract biotic stressors. Cells 2019, 8, 38. [CrossRef]

40. Qu, J.; Ye, J.; Fang, R. Artificial microRNA-mediated virus resistance in plants. J. Virol. 2007, 81, 6690-6699. [CrossRef]

41. Voloudakis, A.E.; Holeva, M.C.; Sarin, L.P.; Bamford, D.H.; Vargas, M.; Poranen, M.M.; Tenllado, F. Efficient double-stranded RNA production methods for utilization in plant virus control. Methods Mol. Biol. 2015, 1236, 255-274.

42. Wang, X.B.; Wu, Q.; Ito, T.; Cillo, F.; Li, W.X.; Chen, X.; Yu, J.L.; Ding, S.W. RNAi-mediated viral immunity requires amplification of virus-derived siRNAs in Arabidopsis thaliana. Proc. Natl. Acad. Sci. USA 2010, 107, 484-489. [CrossRef]

43. Wang, X.B.; Jovel, J.; Udomporn, P.; Wang, Y.; Wu, Q.; Li, W.X.; Gasciolli, V.; Vaucheret, H.; Ding, S.W. The 21-nucleotide, but not 22-nucleotide, viral secondary small interfering RNAs direct potent antiviral defense by two cooperative argonautes in Arabidopsis thaliana. Plant Cell 2011, 23, 1625-1638. [CrossRef]

44. Kaldis, A.; Berbati, M.; Melita, O.; Reppa, C.; Holeva, M.; Otten, P.; Voloudakis, A. Exogenously applied dsRNA molecules deriving from the Zucchini yellow mosaic virus (ZYMV) genome move systemically and protect cucurbits against ZYMV. Mol. Plant Pathol. 2018, 19, 883-895. [CrossRef]

45. Namgial, T.; Kaldis, A.; Chakraborty, S.; Voloudakis, A. Topical application of double-stranded RNA molecules containing sequences of Tomato leaf curl virus and Cucumber mosaic virus confers protection against the cognate viruses. Physiol. Mol. Plant Pathol. 2019, 101432. [CrossRef]

46. Tabein, S.; Jansen, M.; Noris, E.; Vaira, A.M.; Marian, D.; Behjatnia, S.A.A.; Accotto, G.P.; Miozzi, L. The induction of an effective dsRNA-mediated resistance against Tomato spotted wilt virus by exogenous application of double-stranded RNA largely depends on the selection of the viral RNA target region. Front. Plant Sci. 2020, 11. [CrossRef]

47. Melita, O.; Kaldis, A.; Berbati, M.; Reppa, C.; Holeva, M.; Lapidot, M.; Gelbart, D.; Otten, P.; Voloudakis, A. Topical application of double-stranded RNA molecules deriving from Tomato yellow leaf curl virus reduces cognate virus infection in tomato. Biol. Plant. 2021, in press.

48. Holeva, M.C.; Sclavounos, A.P.; Kyriakopoulou, P.E.; Voloudakis, A.E. In vitro produced dsRNA induces resistance against a severe Hellenic CMV isolate in tobacco and tomato. In Book of Abstracts, Proceedings of the 8th International Congress of Plant Molecular Biology, Adelaide, South Australia, 20-25 August 2006; POS-THU-580; Springer: Berlin/Heidelberg, Germany, 2006 ; p. 221.

49. Holeva, M.C.; Sclavounos, A.P.; Kyriakopoulou, P.E.; Voloudakis, A.E. External application of dsRNA of the capsid protein (CP) or $2 \mathrm{~b}$ gene of CMV reduces the severity of CMV-infection in tobacco. In Book of Abstracts, Proceedings of the XIII International Congress of IS-MPMI, Sorrento, Italy, 21-27 July 2007; PS 12-574; Springer: Berlin/Heidelberg, Germany, 2007; p. 286.

50. Borah, M.; Berbati, M.; Reppa, C.; Holeva, M.; Nath, P.D.; Voloudakis, A. RNA-based vaccination of Bhut Jolokia pepper (Capsicum chinense Jacq.) against Cucumber mosaic virus. Virusdisease 2018, 29, 207-211. [CrossRef] [PubMed]

51. Mitter, N.; Worrall, E.A.; Robinson, K.E.; Li, P.; Jain, R.G.; Taochy, C.; Fletcher, S.J.; Carroll, B.J.; Lu, G.Q.; Xu, Z.P. Clay nanosheets for topical delivery of RNAi for sustained protection against plant viruses. Nat. Plants 2017, 3, 16207. [CrossRef]

52. Gago-Zachert, S.; Schuck, J.; Weinholdt, C.; Knoblich, M.; Pantaleo, V.; Grosse, I.; Gursinsky, T.; Behrens, S.-E. Highly efficacious antiviral protection of plants by small interfering RNAs identified in vitro. Nucleic Acids Res. 2019, 47, 9343-9357. [CrossRef]

53. Dubrovina, A.S.; Kiselev, K.V. Exogenous RNAs for gene regulation and plant resistance. Int. J. Mol. Sci. 2019, 20, 2282. [CrossRef]

54. Vogel, E.; Santos, D.; Mingels, L.; Verdonckt, T.-W.; Broeck, J.V. RNA Interference in Insects: Protecting beneficials and controlling pests. Front. Physiol. 2019, 9, 1912. [CrossRef]

55. Christiaens, O.; Dzhambazova, T.; Kostov, K.; Arpaia, S.; Joga, M.R.; Urru, I.; Sweet, J.; Smagghe, G. Literature review of baseline information on RNAi to support the environmental risk assessment of RNAi-based GM plants. EFSA Supp. Publ. $2018,173$. [CrossRef] 
56. Roberts, A.F.; Devos, Y.; Lemgo, G.N.Y.; Zhou, X. Biosafety research for non-target organism risk assessment of RNAi-based GE plants. Front. Plant Sci. 2015, 6, 958. [CrossRef] [PubMed]

57. Casacuberta, J.M.; Devos, Y.; du Jardin, P.; Ramon, M.; Vaucheret, H.; Nogué, F. Biotechnological uses of RNA interference in plants: Risk assessment considerations. Trends Biotechnol. 2015, 33, 145-147.

58. Ramon, M.; Devos, Y.; Lanzoni, A.; Liu, Y.; Gomes, A.; Gennaro, A.; Waigmann, E. RNAi-based GM plants: Food for thought for risk assessors. Plant Biotechnol. J. 2014, 12, 1271-1273. [CrossRef] [PubMed]

59. Lundgren, J.G.; Duan, J.J. RNAi-based insecticidal crops: Potential effects on nontarget species. Bioscience 2013, 63, 657-665. [CrossRef]

60. Ossowski, S.; Schwab, R.; Weigel, D. Gene silencing in plants using artificial microRNAs and other small RNAs. Plant J. 2008, 53, 674-690.

61. Schwab, R.; Ossowski, S.; Riester, M.; Warthmann, N.; Weigel, D. Highly specific gene silencing by artificial microRNAs in Arabidopsis. Plant Cell 2006, 18, 1121-1133. [CrossRef]

62. Konakalla, N.C.; Kaldis, A.; Berbati, M.; Masarapu, H.; Voloudakis, A.E. Exogenous application of double-stranded RNA molecules from TMV p126 and CP genes confers resistance against TMV in tobacco. Planta 2016, 244, 961-969.

63. Numata, K.; Ohtani, M.; Yoshizumi, T.; Demura, T.; Kodama, Y. Local gene silencing in plants via synthetic dsRNA and carrier peptide. Plant Biotechnol. J. 2014, 12, 1027-1034. [CrossRef]

64. Jiang, L.; Ding, L.; He, B.; Shen, J.; Xu, Z.; Yin, M.; Zhang, X. Systemic gene silencing in plants triggered by fluorescent nanoparticle-delivered double stranded RNA. Nanoscale 2014, 6, 9965-9969. [CrossRef] [PubMed]

65. Zhang, H.; Demirer, G.S.; Zhang, H.; Ye, T.; Goh, N.S.; Aditham, A.J.; Cunningham, F.J.; Fan, C.; Landry, M.P. DNA nanostructures coordinate gene silencing in mature plants. Proc. Natl. Acad. Sci. USA 2019, 116, 7543-7548. [CrossRef] [PubMed]

66. Patil, B.L.; Raghu, R.; Dangwal, M.; Byregowda, M.; Voloudakis, A. Exogenous dsRNA-mediated field protection against Pigeonpea sterility mosaic emaravirus. J. Plant Biochem. Biotechnol. 2021. [CrossRef]

67. Worrall, E.A.; Bravo-Cazar, A.; Nilon, A.T.; Fletcher, S.J.; Robinson, K.E.; Carr, J.P.; Mitter, N. Exogenous application of RNAiinducing double-stranded RNA inhibits aphid-mediated transmission of a plant virus. Front. Plant Sci. 2019, 10, 265. [CrossRef] [PubMed]

68. Timmons, L.; Court, D.L.; Fire, A. Ingestion of bacterially expressed dsRNAs can produce specific and potent genetic interference in Caenorhabditis elegans. Gene 2001, 263, 103-112. [CrossRef]

69. Rizos, H.; Gunn, L.V.; Pares, R.D.; Gillings, M.R. Differentiation of Cucumber mosaic virus isolates using the polymerase chain reaction. J. Gen. Virol. 1992, 73, 2099-2103.

70. Sambrook, J.; Russell, D.W. Molecular Cloning: A Laboratory Manual; Cold Spring Harbor Laboratory Press: New York, NY, USA, 2001; p. 2100.

71. Akbergenov, R.; Si-Ammour, A.; Blevins, T.; Amin, I.; Kutter, C.; Vanderschuren, H.; Zhang, P.; Gruissem, W.; Meins, F., Jr.; Hohn, T.; et al. Molecular characterization of geminivirus-derived small RNAs in different plant species. Nucleic Acids Res. 2006, 34, 462-471. [CrossRef] [PubMed]

72. Blevins, T.; Rajeswaran, R.; Shivaprasad, P.V.; Beknazariants, D.; Si-Ammour, A.; Park, H.S.; Vazquez, F.; Robertson, D.; Meins, F., Jr.; Hohn, T.; et al. Four plant Dicers mediate viral small RNA biogenesis and DNA virus induced silencing. Nucleic Acids Res. 2006, 34, 6233-6246. [CrossRef]

73. Blevins, T.; Rajeswaran, R.; Aregger, M.; Borah, B.K.; Schepetilnikov, M.; Baerlocher, L.; Farinelli, L.; Meins, F., Jr.; Hohn, T.; Pooggin, M.M. Massive production of small RNAs from a non-coding region of Cauliflower mosaic virus in plant defense and viral counter-defense. Nucleic Acids Res. 2011, 39, 5003-5014. [CrossRef] 